University of Louisville

ThinkIR: The University of Louisville's Institutional Repository

Electronic Theses and Dissertations

1940

\title{
A brief history of Woman's Missionary Union, Southern Baptist Convention.
}

Pearle Bourne

University of Louisville

Follow this and additional works at: https://ir.library.louisville.edu/etd

Part of the Civic and Community Engagement Commons, and the History of Religion Commons

\section{Recommended Citation}

Bourne, Pearle, "A brief history of Woman's Missionary Union, Southern Baptist Convention." (1940).

Electronic Theses and Dissertations. Paper 1678.

https://doi.org/10.18297/etd/1678

This Master's Thesis is brought to you for free and open access by ThinkIR: The University of Louisville's Institutional Repository. It has been accepted for inclusion in Electronic Theses and Dissertations by an authorized administrator of ThinkIR: The University of Louisville's Institutional Repository. This title appears here courtesy of the author, who has retained all other copyrights. For more information, please contact thinkir@louisville.edu. 
University of Loulsvilie

A

Briof History of Woman's Miss Ionary

Union, Southern Baptist Convention

\author{
A Dissertation \\ Submitted to the Faculty \\ of the Graduate School of the Un1versity of Loulsville \\ In Partial Fulfiliment of the \\ Requirements for the Degree \\ of Master of Arts
}

Department of History

By

Pearle Bourne

Year

1940 
NAME OF STUDENT:

Pearle Bourne

TITLE OF THESIS: A Brief History of Noman's Missionary Union, Southern Baptist Convention

APPROVED BY READING COMMITTE COMPOSED OF THE FOLLOW ING MEMBERS :

NAME OF DIRECTOR: HeC.Matcalue DATE: $\frac{\operatorname{lal} 12,1940}{4}$

m.

$5-26$ 
A

\section{BRIEF HISTORY OF WOMAN'S MISSIONARY UNION, SOUTHERN BAPTIST CONVENTION}

by

Pearle Bourne 
OUTLINE 
THE OUTLINE

Page

I INTRODUCTION $\ldots \ldots \ldots$

II THE DAY OF SMALL THINGS - - - - - 4

A. BEGINNINGS

B. BAPTIST UNITING

C. INFLUENCES PAVING THE WAY

D. STEPS LEADING TO ORGANIZATION

III THE SUMMONS TO A GRONING TASK 1888 - 1908

31

A. ORGANIZATION - 1888

B. THE WORK ESTABLIS HED

C. EVENTS OF THE FIRST DECADE

D. CHANGING CONDITIONS IN A NEW DECADE

E. EVIDENCES OF GROWTH

IV A DECADE OF GOLDEN EVENTS 1908 - 1918 -

A. THE ROMANCE OF A DECADE

54

B. FAR-REACHING EVENTS

C. A CHAIN OF GOLDEN EVENTS

V DAYS OF EXPANSION 1918 - 1928 - - - -

A. EXPANDING WORK

B. WOMEN LEADING THE WAY

C. EXPANSION YEAR BY YEAR

VI A DECADE OF ANNIVERSARIES AND PROGRESS 1928 - 1938

A. CONTINUED GRONTH

B. THE DECADE OF ANNIVERSARIES

C. SUMMARY

D. YEAR BY YEAR THROUGH THE DECADE

VII APPENDIX - . - - . - . - . - 121

A. PARTIAL LIST OF EARLY SOUTHERN BAPTISTS WOMAN'S MISS IONARY SOCIETIES

B. CHARTS AND TABLES 
INTRODUCTION 
The Woman's Missionary Union of the Southern Baptist Convention has a past of more than common interest. No romance of modern times has been more thrilling than that of the Woman's Missionary Union. In answer to the cry of William Carey, "Expect great things from God, attempt great things for God", ${ }^{1}$ women began to manifest deep interest in progress of the Kingdom, which interest has been a continually growing thing through fifty years. The material for this thesis "A Brief History of the Woman's Missionary Union, Southern Baptist Convention" has been gathered during close association with the organization for twelve years, through visits to the state headquarters of seventeen state Woman's Missionary Unions, through visits to the Foreign Mission Board, Home Mission Board, Sunday School Board and through observing the work in four of the European countries. Having access to the files of Woman's Missionary Union, Southern Baptist Convention, the Southern Baptist Theological Seminary library, the files of the missions in Italy and the Theological Seminary library in Hungary has been of inestimable value.

1. Smith, Niles M., The Torch Bearer, p, 79 
No attempt has been made to relate in detail the work of the organization but rather to record briefly the highlights of events and progress.

The material has been divided into seven sections. The five sections, II-VI, each represents a distinct period of history. The last section is composed of tables and charts. The material gathered sets forth the steps and movements leading to the national organization, the missionary zeal which called this organization into being and which has actuated its activities, the conditions surrounding the organization, the chronological arrangement of the events which show the progress made in five decades of the life of the movement and the outreach of the movement into the world. Through these pages we shall see that in the forming of policies and plans the Woman's Missionary Union has recognized the importance of the people back of the local organization, their thoughts and convictions.

Section II deals with the steps leading to the organization of the Woman's Missionary Union and the zeal which called it into being and which has motivated it through fifty years.

Section III is divided into two parts. The first part deals with the actual organization, the foundation in plans and policies, standards and aims which are 
interrelated and flow in steady rhythm through the years. The second part pictures the events in the second decade, a decade in which women were passing from days of uncertainty, regarding the work of the organization, to days of permanency and assurance in face of new and growing tasks.

Section IV covers the third decade, which was one of expansion. Many events occurred which have proved to be history making events.

Section V reviews the fourth decade and attempts to show the lines along which the organization was expanding in additional workers, in new Departments, enlarged headquarters, home and foreign growth, new projects and anniversaries.

Section VI records the events of the present decade in which we see the structure which has been built upon the foundation of policies, plans, program and power laid in the early decade. The growth of the work has been phenomenal. This decade shows progress in numerical and spiritual stature. The accomplishments of this decade would lead us to feel that these past fifty years are only a parenthesis in the eternity of missions and that movements which have been set in motion are pinioned to eternity. 
II

THE DAY OF SMAT工 THINGS 
II

THE DAY OF SMALL THINGS

I BEGINNINGS

a- Early Baptists in the South

b- Missionary Fires Kindled

c- Women's Response to the Call of Modern Missions

II BAPTSTS UNITING

a- Rice, a Unifying Agent

b- The Triennial Convention

c- Societies and State Conventions

III INFLUENCES PAVING THE WAY

IV STEPS LEADING TO THE ORGANIZATION

a- Sailing of the Shucks

b- Women's Societies Recognized

c- Southern Baptist Convention Organized 1845

d- Women meet for Prajer

e- Federations Organized

f- Appointment of Central Committees

8- Ceneral Neetings Held. 
THE DAY OF SNALI THINGS

To understand the plant we must know the soil out of which it sprang. 'To understand the growth of the missionary work of Southern Baptist women through the Woman's Missionary Union we must trace its roots back into the early days, examine the soil out of which it grew and by which it is nourished.

\section{BEGINNINGS}

Since the Woman's Missionary Union is a part of the Southern Baptist Convention and its history is ours, a glance of these early beginnings will give the setting for the birth and growth of the organization known today as the Woman's Missionary Union, Southern Baptist Convention.

EARLY BAPTISTS
In September 1682 a company of messengers from Boston were in Kittery, Naine, on invitation to organize Baptist believers into a church. Before the close of the year the group was driven from the colony. The pastor, William Screven and the whole church decided to seek a new home. They settled in 1683 near the present site of Charleston, South Carolina.1

1. Heck, F.E.S., In Royal Service, pp. 12-14 
It is interesting that early in the life of this group who organized the First Baptist Church of Charleston, missions, especially missions to the Indians, had a place

The first association of Baptists was organized in 1707 in Philadelphia. In 1751 the second was started in Charleston, South Carolina. North Carolina had the third in 1758. Although Virginia was the fourth with an association it was the first to have a state-wide organization.1 These Baptists pled for religious freedom. When the Constitution of the United States was being formed, Baptists were eager for it to be clear on religious freedom. John Leland, who was a preacher chaired a committee which decided to correspond with Baptists in other states and to address a petition to President Washington regarding religious freedom. In reply Washington assured Baptists of "His readiness to cooperate with them in attaining such farther security as might satisfy them. "2 The amendment was made and is the religious liberty clause of the constitution as it is today.

MISSIONARY The background against which missionary FIRES

fervor must be viewed are numerous.. Among them are the "Great Awakening" of $1740 * 1$, the subsequent

1. Cox, Etheleen B., Following in His Train, p. 32

2. Heck, F. E. S., Op. Cit., p. 9 
wars involving the colonists and eventuating in the American Revolution. The Greak Awakening had kindled a zest for spreading the gospel but following the Revolutionary war skepticism had sqept the country. However, as is often true, people move in extreme directions. In 1792 William Carey's shoemaker's hammer tapped out the missionary reveille of Christians and modern missions came into being. The first sign of response to the new missionary movement on the part of Baptists was in 1792 when there was a call to a concert of prayer. The New York Missionary Society, an interdenominational organizetion, came into being in 1796 . In 1800 a far-reaching revival, the Second Awakening, began. This movement reached into the colleges as well as into churches. Williams college was one wich felt the influence of this awakening. As a result the famous haystack prayer meeting occurred and the banding together of six young men whose definite purpose was to propogate the gospel. Today the place is marized by a slab bearing the following inscription:

The Field is the World

The Birthplace of Americen Foreign Missions 1806

Samuel Mills

Samuel Nott

James Richard

Francid.L. Robbins

1. Limouze, Arthur, Homeland Harvests, p.6 
Harvey Loomis
Byram Green

It as also in 7800 that women manifester a ne interest through the formation of the first Voman's Missionary wociety. This too place in Boston. The Society was composed of eight Baptist omen and six Congregational women. It origirated in the mind of Mary vebb, a cripple, who was for more than sixty years a member of the Second Baptist Church of Boston. Although the greater number of members were Baptists, this organization was not strictly Baptist but was a forerunner of the Baptist Noman's Misoionary Society.I

WOMTN Parallel to this society in the north was the RESPNSE

Juvenile Missionary and Educational Society in the south, organized in 1802 by Dr. Richard Furman, who was by this tine the pastor of the First Baptist Church of Charleston, South Carolina. The purpose of the society was misuions to the Catawba Indians in whom the Charleston church was alreaoy interested. 2

In 1.802 a hisoionary magazine, the Georgia Analytical Depository which publisbed letters from Dr. Caret, appeared and stimulated interest. 3

1. Bucy, Wilma, The Why and How of H. U., p. 6

2. See Above, p. 5

3. Heck, F.E. 3., Op. Oit., p. 14 
The first woman's society in the South of which there is a record is the society of Edisto, South Carolina. The date of the organization is uncertain. It probably occurred between 1809 and 1811. We know that ilrs. Hepzibeth Townsend was the leading spirit and that by 1812 the society had given $\$ 122.50$ for the Catawba Indians. 1 In 1810 the American Board of Commissioners for Foreign lifissions was organized.

In 1812 the Judsons and Luther Rice sailed from America for India. Soon after sailing the three, through intensive study of their Bibles, became Baptists. Rice returned to America to arouse American Baptists and other Christians to the need and to their opportunity. In 1814 the Mission Convention of Baptists came into being. It was to promote plans for missions in the west. In 1832 this group became the American Baptist Home Wission Society. 2 Between 1812 and 1825 many organized efforts came into being. They were the American Education Society, the American Bible Soclety, the Sunday School Union and the American Tract Society. In face of this new interest and the flaming advocate of missions, Luther Rice, Women's Missionary Societies sprang up rapidly

1. Bucy, Wilma, op. Cit., p.34

2. Limouze, Arthur, Op. Cit., p.3 
among Baptist women. In 1813 the "Female Missionary 1

Society of Richmond" was formed. North Carolina women followed in 1815 and 1816. Rice visited Edenton in 1817 and Raleigh in 1818 and organized the women. In one state after another societies were formed in response to Rice's appeal. The organizations in Georgia began in 1817, in the District of Columbia in 1818, In Kentucky in 1822, in Alabama in 1823, in Arkansas in 1828, in Mississippi in 1832, and in Texas in 1832.

\section{BAPTIST UNITING}

RICE AN To Rice more than any other one we owe the AGENT gathering of American Baptists together in one body for missionary endeavor. This effort resulted in a convention being called. It met in Philadelphia, on May 18, 1814, with thirty-three delegates. TRIENNIAI The name "The General Missionary Convention of CONVENTION the Baptist Denomination in the United States of America" was chosen. Te name, however, was changed to "Triennial Convention" and Doctor Richard Furman, who was the pastor of the Pirst Baptist Church of Charleston and also the founder of Furman University in South Carolina, was chosen president.

By the time of the Triennial Convention in 1817 the report

1. Heck, F.E.S., Op. Cit., p. 24

2. Ibid., pp. 25-29 Convention Records, 1814, p. 4 
showed 187 societies. 1 In Rice's report reference is made to the rapid growth in women's societies and contributions, "The great numbers and rapid increases of these laudable Female Institutions cannot fail to create emotions, the most lively and gratifying hope and anticipation of the most ardent and eminating nature."2 SOCIETIES FORIED Vomen were ever glad to be heralds STATE CONVENTIONS ORGANIZED of a resurrection truth, so local societies were springing up in different sections. No State Convention of Baptists had been organized before 1821, so few records are available. The Constitution of the "Female Societ for Foreign lissions,"3 a local organization for Fredericksburg women which was formed in 1814, is the earliest constitution known. This was discovered in an old garret in Athens, Georgia, in some letters from Mrs. Lucy Thornton vritten to Mrs. Lucy Cobb who had moved from Virginia to Georgia. The constitution contains ten articles. The officers' names sound a Iittle strange today. There are "Directress, ViceDirectress, Treasurer, Correspondent Recorder and

1. Convention Records, 1817, po 6

2. Loc. Cit., p.7

3. Unpublished Letters, Office of First Baptist Church Athens, Georgia 
fifteen hanagers."I The dues required were at least fiftytwo cents a year. Mention is made of a local society in Kentucky as early as 1816. This society supported a school for Indians with eight children enrolled. 2

In 1818 there is a record of several local societies being formed among girls from six and seven to twelve and fourteen "To save from the purchases of delicacies so they could assist." 3 The few available recoras of early societies show the careful system of reporting. In 1822 the Bethel Female Societ was organized near Hopkinsville, Kentucky, and a careful record of the twenty-four members was rept. The Heo Female Cent societ in the fifth annual report to the church has an interesting entry. Among the list of contributions is this itern "Negro Amy nine cents." 4 It is interesting to note that other groups were giving attention to the Negroes. The record from Nashville, Tennessee dates back to 1820 "Second Lord's Day in September 1820, received as members Sara and Juno, servants of Mrs. Beck." 5

1. Unpublished Letters

2. Perry, Mrs. E. N., History of Kentucky W.M.U., p.18 3. Heck, F. E. S., Op. Cit., p.45

4. Ibid., p.39

5. Minute Boor (unpublished) 
Seven Alabama Societies played an important part in the organization of the Alabama state Baptist Convention in 1823, which organization was a general organization of Baptists and not a women's societios convention. However, the societies plawing a part in the work were Bethel, Jonesboro, Salem, Clariborne, El ton, Roupe's Valley and Greensboro. 1

In the spring of 1828 three women in Lawrence county, Arkansas, wrote to keverend javid orr, an outstanding pastor of issouri, about the need in Arkansas. He came and in a few years organized the Spring River Association. In 1847 the Arkansas State Baptist Convention was organized and received its first legacy from a woman. Mrs. Annette Bledsoe, educated at Judson College, Alabama went to Jacogdoches in 1835. The Domestic Board (later known as the Home Mission Board) gave her tracts and testaments and she began among the women, the first woman's missionary worls in the state while Texas was still a part of lexico. After rexas became a republic, a Baptist church at ivacogdoches could meet openly, and work grew. By 1839 there were sixty-five women in the society. In $1841 \mathrm{krs}$. Bledsoe's sister married

1. Minutes of Alabama State Baptist Convention, 1823, p.22 
General Houston. They joined the small group in keeping up a central work at Independence until the Education Society was formed and the State Convention organized.1 This was in 1845, the same year that Baylor University was founded. After Mrs. Bleds oe's husband died in 1849 she traveled in Texas in the interest of mission work among the women and children. She organized societies in twenty-five localities in the state. Mission fervor of the early part of the nineteenth century was implemented by offerings of the churches. These offerings were increased by gifts of the Female Cent Society, composed of women whose concern for the spiritually needy areas of America brought them together in organizations which added their mites to the gifts of the churches. In these societies lay the seed of the various Women's Missionary Boards, destined to make their influence felt in later years. 2

INFLUENCES PAVING THE WAY

Farmers, planters, lawyers, doctors, merchants, preachers, teachers, poor white and slaves were the concomitant parts of an era which has passed, but from which

1. Copass, Mrs. B.A., Fifty Golden Years in Texas, p. 11

2. Limouze, Arthur, Op. Cit., p.17 
Page 14

remains much golden fruitage of high ideals, true chivalry, respect for knowledge, Christian standards, gentleness and honor and truth.

By 1888 the world had changed and the women of 1888 differed from the women of 1800. Time had traced lines of thought, which added to rather than detracted from the interest of their faces. The effects of social, economic, and religious changes had been felt. The American Industrial Revolution had brought many changes. By the introduction of steam, water transportation was improved. Along the Mississippi and the Ohio, shipyards were rapidly built, for there was more business than could be handled. By 1843, railroads were beginning to link many of the short lines and soon there was emerging an outline of a national system of transportation and communication. Inland cities take on more importance with the coming of a railroad system. Atlanta had grown to 10,000 by 1860.1 Roads were being constructed under state charters. There was a demand for a Federal system of wagon roads and better mail service. All of this facilitated travel and also the movement of goods and crops. Early in the century basic changes in the whole textile business were being made. By 1840 cotton mills had

1. Cole, Arthur Charles, Irrepressible Conflict, p. 14 
gained importance. Manufacturing plants were growing up near the raw materials.

The lumber industry was growing. Sawmills were springing up. Coal was being produced and the iron industry was also beginning.

There were changes in agriculture. After Whitnev's invention of the cotton gin in 1792, America had become the important source of cotton supply. Cotton was king in the South. With increased cotton growing, slavery seemed needed more than ever, and the sale of slaves became a source of large profits. Large quantities of rice were produced. Sugar cane was grown in lower Louisiana. The South was producing 27 per cent of the total wheat crop by 1849. The government had no experimental farms, but individual farmers made contributions to improving agriculture, like J thro Jones, the breeder of new cotton strains. Later agriculture colleges were in demand. The South had experienced territorial expansion and growth in population. The population had increased and the lan had joubled from 1776 to 1836. Between 1840 and 1869 over six and one-half million people came to America. This was due in part to the potato famine in Ireland, liberel homestead laws, public works like the Erie Canal, and the opening up of the West. Later the golf rush of

1. Hawk, Emory, Economic History of the South, p. 200 2. Ibid., p. 223 
of 1848 led great numbers westward. By emigration Virginia had lost 26 per cent of her native born free inhabitants; South Carolina 36 per cent and North Carolina 31 per cent.

Besides the influences of economic changes there were also social, educational and religious influences paving the way for the organization which has been mentioned. Some southern cities like New Orleans, Baltimore and Savannah were becoming centers of immigration. Southerners were sensitive to the bearing of immigration on slavery. The abolitionist movement was under way in the forties. The South, socially, was divided into the aristocracy, which was made up partially of the plantation owners, merchants and the large famers who had comfort, luxury, and elegance; the midale class, made up of small slave holding planters, professional men, and tradesmen; and the lower class made up principally of tenant formers and finally the slaves. The women who were interested in missions came largely from the midrle class with some from the upper class. The names of some of the missionarv workers of this period are names of outstandino families and the decendants of many such families are still active in religious wor?. Such families as Carters are today represented in Mrs. Carter Wright, Stewardship Chairman for Woman's Missionary Union.

1. J̦awk, Fmory, op. Cit., pp. 300-378 
John Tyler of Virginia is another name which still has connections trrough the person of Mrs. W. C. Tyler, Recording Secretary of Woman's Missionary Union. Mrs. Annette Bledsoe who did so much mission work in Texas represents another outstanding family of whom Albert $J$. Bledsoe who wrote an "Fssay on Liberty and Slavery" ${ }^{1}$ was a member. The North and the South differed in their social system. The social structure of the South was that of a caste system while that of the North was based on free wage labor; the South pivoted on the production of a few staple crops while the North experienced a diversified production of farm and factory.

Prior to the fifties many Southern sons and daughters received their higher education either in England or in the North. The idea of common schools was gaining momentum under Horace Mann. Many Female Seminaries were growing up. Increased sectionalism led to more rapid development of professional training, the establishing of medical colleges and the starting of commercial education. There was a movement for more colleges and universities in the South. Agricultural changes led to the demand for agricultural education and state agricultural colleges began to spring up. Theological schools were also established in this period.

1. Cole, Arthur, op. Cit., p. 55 
The Presbyterian Seminary was ectablished in Lebanon, Tennessee and the Southern Baptist Theological Seminary at Greenville, South Carolina in 1859. The denominational colleges and seminaries grew up partially to provide religious workers. The field for mission work in the midrle west was recognized and workers were needed. During this period western society was taking shape, immigration was increasing, groups were becoming self-conscious, slavery agitation was heightening, and reforms were being effected.

The women of the midale class spent much of the leisure which had come to them with increasing relief from domestic routine in social and religious movements. The Temperance movement gained in importance in the forties. The women's rights movement was launched in 1848. Other social ouestions were receiving attention. Fannie Wright advocated marriage based on moral obligation. She also attacked the conservative attitude of churches toward public welfare. Others were interested in removing discrimination against the female sex. In 1848 Dorothea Dix championed the cause for public care for the indigent insane. Community life centered in the church. ${ }^{1}$ The fifties saw the growth of the Sunday School movement and activities. The great revivel of 1858 had far-reaching influences. However, by the outbreak of the 1. Stephenson, George M., American History to 1865, pp. 459- 
Civil War most branches of the Christian faith were em1 broiler in the slavery question.

Many groups were coming together in conventions. The idea was not new to Baptist women. The International Typographers Union was organized in 1852, the Commercial Convention met in 1852, the Merchants Convention in 1859. The idea of convention seemed to permeate many groups. STEPS LEADING TO THE ORGANIZATION

There is danger in perio izing historv, for the roots of one period lie deep in the past of another. This is true of the vear 1888, the Aate of the organization of the Woman's Missionary Union, Southern Baptist Convention, for we must go back beyond that year to see some of the steps which led up to the interest in and the formation of a general missionary organization for the women of the Baptist churches of the South.

The main steps were: (1) the sailing of the Shucks for China, (2) recognition of Women's Societies and the subsequent encourggement to women, (3) the unifving steps of the organization of the outhern Baptist Convention, (4) the separate meeting of women which was called for praver and which gave the women a sense of common interest, (5) the organization of Women's Federations which united the efforts of small

1. See Below, p.23

2. Cole, Arthur, Op. Cit., p. 148 
groups of local societies, ( 6 ) the appointment of Central Committees in the states, which committees served as executive bodies, attempting to unify the work of the societies in the separate states and (7) the general meeting which called together the several Central Committees. THE SHUCKS The annual missionart meeting of the First SAIL Baptist church, Richmond, Virginia, was held on an April Suncay. "Picture quaintly but beautifully dressed ladies as the-r alighted from their convevances in 1835, lingered awhile in the church vard and then setting their voluminous skirts and folding their mittened hands composed theinselves to hear the Anniversary sermon preached by J.L. Shuck. Four months later he and his bride were to sail to China as the first Baptist missionaries to China. Mrs. Shuck was the first American woman who gave her life for the wonen of that land." 1

The Society of Beulah, Virginia, helped to educate Mr. Shuck at the Seminary in Richmond (now Richmond University). When he decided to go to China his clothing was made of Virginia cloth by Virginia women.

SOCIETIES News of the going out of the Shucks was an RECOGNIZED impetus to the missionary interest among women. Men were beginning to recognize the work of the women. Al-

1. Heck, F.E.S., Op. Cit., p. 55

2. White, Blanche, Saver to Serve, p. 17 
though the work was still in its infanor, recognition gave encouragement to the few weak societies and to the groups of women who desired to granize for mission work but were shy. Kentucky and Virginia are notable among. the states giving, recognition publicly to the women. As early as 1835 at a meeting of Kentucky Baptists public recognition was given the Georgetown Female Society for a gift of $\beta_{10}$ sent for the Convention expense. Mr. W.C. Buck presented the gift for the women. In 1839 at the Kentucky Baptist State General Association attention was called to a gift of $\$ 49.10$ from the Louisville Female Missionary Societ. The minutes of the Kentucky Baptist Generel Association report a gift of 31 from the same society. in 1840 . We also gather this interesting notation from the report. "It would also result in great good to have organized, as far as practicable, Female Auxiliar Societies, for experience has proven that in works of benevolence the $f$ male's hand knows no miser's grip, but moves in obedience to the generous impulses of the female's heart."

S.B.C. Baptists were not different from other groups ORGANIZTED during this period. There was dissention in many groups. Andover Theological Seminar had been founded

1. Chronicles of General Association of Kentucky Baptist, p.14 2. Kentucky General Association Minutes, 1839, p.19

3. Kentucky General Association Minutes, $1840, \bar{p} .16$ 
by those opposed to the extreme Calvinist party in 1808; The separation of the 0ld School and the New School in the Presbyterian church come in 1837 and a further split over the slaverv question in 1857. During this period of change, Bantists had been at work. The agency which had unified Baptists efforts since 1814 was the Triennial Convention. 1845 saw the disruption of the Priennial Convention. In the two previous Conventions slaver and anti-slavery men began to draw off on different sides. The Triennial Convention took the stand that it could not appoint, as a missionary, any man who was a slaveholder. Southern Baptists felt the could not support an agency by their mission gifts which made such restrictions. The issue was bringing dissention. A group of Northern Baptiats met in Bost on in 1843 and organized a Free Mission Society. This Society felt it could not cooperate with the Foreign Mission Board of the Triennial Convention because of its affiliation with Southern Baptists. The Baptists of the South felt that Northern Baptists had no right to question the virtue of the owners of slaves. There was no question of doctrinal difference, but the breach on the slavery question grew wider. The result was a desire on the part 
of both North and South to organize into separate bodies. At the call of the Board of Managers of the $V_{\text {irginia }}$ Foreign Missionery Society delegates were selected to attend a meeting of Southern Baptists on May 8, 1845 in Augusta, Georgia. Three hundred and twenty-eight delegates from Marrland, Virginia, North Carolina, South Carolina, Louisiana, Georgin, Alabama, Kentucky and the District of Columbia were able to attend. The purpose of the meeting was stated in a resolution.

"Resolver that for perce and harmont, and in order to accomplish the greatest good, and for the maintenance of those Scriptural principles on which the General Missionary Convention of the Baptist Denomination of the United States was originally former, it is proper that this Convention at once proceed to organize a Society for the propogation of the Gnspel." I

After a five day session the vote was taken to organize into the Southern Baptist Convention. Mission work had been carried on $b$ some churches but it was often done spasmodically. To give direction to the mission effort, two boards, both agencies of the newly organized Southern Baptist Convention, were created. They were the Foreign Mission Bnard and the Home Mission Board. These boards not only were to unify the work of the churches but to plan for mission expansion. The revolutionary happenings in Europe

1. Cox, Ethleen B., Op. Cit., p. 41 
had disturber the status cuo of the establisher church. Catholicism defended itself and became more active on the mission fields. Some of the Irish and German immigrants were radicals who were more anti-Catholic than some Americans. By the early forties there was vocal opposition between a certain element in the Catholic church and in the Protestant church. This crusare against Catholicism reflected itself in the political party known as the Native American party or the Know Nothing party. It was also reflected in the attitude towards immigrants from Turope settling in the Mississippi Valley. It was believed by many that this was simoly another move by the papacy to establish itself more firmly. Fmphasis was put on securing men and money for the west to stem the tids of Catholicism. Organizations of $\mathrm{v}$ rious types became active during this period. Some of them were the American Bible Society, the American Tract Society, the Boston Ladies' Association for the Evangelizing of the West, the American Protestant Association for the purpose of uniting members of various denominations to counteract the efforts of Rome. This effort may account for the rapid increase of missionaries of the Domestic Mission Board in the first few years of its existence.

The year 1849 was the date of the going of the first 1. Stephenson, George M., American History to 1865, pp.436-437 
single woman missionary to China, Miss Harriet A. Baker of Powhatan County, Virginia. The Domestic Mission Board had six missionaries the first year, fifty-seven the third year. By 1853 twenty cities were stations of this Board.

The Civil war came, with consequent curtailment of the work. In 1865 the remnant of men came home. In a surprisingly short time after this the churches and societies were again taking up the threads of life. During the early years of reconstruction there was little to give. In 1869, however, three times as much was given as three years before.

WOMEN MEET It is not strange that in 1868, when the FOR PRAYER

Convention met in Baltimore, the minutes should record the first general meeting of southern Baptist women for missions. Women from all parts of the south had come. It was an opportunity to touch a wide circle of American women for other women. Mrs. Anna Graves seized 1t. At her request the ladies in attendance were asked to meet in the basement of the church. Mrs. Graves told the ladies of what her son, Dr. Roswell Graves, had said about it being Impossible for a man to enter the homes of the Chinese women and begged them to go home and organize societies to 
raise money and employ a native Bible woman. The Female Missionary Praver meeting had been organized in Baltimore in 1867. Gifts had been made to missions. Mrs. Graves suggested mite boxes for this purpose. The suggestion took root and women began to pray for Mrs. Graves' son and to make small contributions. 1

FEDERATIONS In October 1871 there was organized at ORGANIZED

$$
\text { Baltimore "Woman's Mission to Woman", } 2 \text { an }
$$
organization which sought to enlist Baptist women of the South. This was the first federation of missionary organizations in the history of Southern mission work. In 1872 the women in Richmond, Virginia formed a federation. 3

CENTRAL COMAITTEES
In 1874 the Foreign Mission Board recommended the appointment of Central Committees to unify the work of the Noman's Missionary Societies in the states. On January 10, 1875, South Carolina appointed a comittee which was confimed by the state Convention in 1876.4 North Carolina followed in 1877. When the Southern Baptist Convention met in Nashville in 1878 it recommended the "formation of a Central comittee in each state with the task of forming Woman's Missionary Societies

1. Wharton, Mrs. H. M., Ready Pens for Willing workers, p.75

2. Mallory, Kathleen, Mañal of W.M.U. Methods, p.94

3. Ibid., p.94

4. Perry, Mrs. E.N., W.M.U. Paths, p.6 
in Baptist churches."I Hence Kentucky, Georgia, Mississippi and Texas formed such committees in 1878 and 1879. In a few years all the states except Maryland had them. The first hint of a general organization came from the committee on Woman's Work, appointed by the Southern Baptist Convention in 1879. The committee suggested that "The time might have come when it would be well to have a Central Committee of the Central Committees to combine their efforts."2 It was further suggested that the Foreign and Home Mission Boards jointly appoint a woman as Superintendent of Woman's Work. The Committee on Woman's Work made the sugges. tion in 1882. No immediate results of these suggestions were seen. However, the Kentucky General Association passed a resolution as follows: "We would tenderly and lovingly urge the immediate formation of women's societies in every church throughout the land."3 Fiftysix years later there were 34,594 Woman's Missionary Union organizations." 4

Likewise in 1882 a monthly missionary magazine, The Heathen Helper, began publication, with Miss Agnes

1. Perry, Mrs. E. N., W.M.U. Paths, p. 7

2. Report of Convention, 1880

3. Minutes of Kentucky Baptist Association, 1882, p. 11

4. Executive Secretary's Report, 1938, p. 3 
Osborne of Louisvilie, Kentucky, as editor and the secretaries of the Central Committees of Georgia, Louisiana, Maryland, Mississippi, Missouri, North Carolina, South Carolina and Texas as assistant editors. The subscription price was fifty cents a year.

GEIVERAL By 1885 the report made to the southern BapMEETINGS

tist Convention by the Forelgn Mission Board said: "The comparative easy financial condition of our Foreign kission Board for the year past is in Large measure due to the work of the Woman's Missionary Societies. The regular contributions of our churches are not diminished by the collections of the Woman's Socleties but rather stimulated and increased by their work and influence." I The work was growing and yet in its growth it was but the "Baby figures of the giant mass of things to come." The suggestions made by severa 1 groups had been taken and Central Committees had been formed. The first general meeting of Central Committees was held when the Convention met in Waco, Texas. The meeting was held in the Hethodist church. This brought together Central Committees and State Leaders. Mrs. S. R. Ford of Missouri presided. Mrs. Martha Crawford of China spoke. Mrs. HoLlingsworth of Kentucky spoke on young people's work.

1. Broadus, Eliza, Some Early History, p. 3 
In 1884 a second general meeting was held in Baltimore, Maryland. To this meeting the states had been asked to send formal reports of their work. The following resolution was passed: "Resolved that the societies here represented make the Union meeting permanent; to meet annually during the session of the southern Baptist Convention; the Central Committees of the states in which the Convention is held having charge of the meeting that year."I At the same time the men in the Convention manffested some apprehension. During a debate on the report of Woman's Work suggesting an organization, one of the men said "The day is a long way off when our southern brethren will deem it wise. I do believe it is the entering wedge to woman's rights and platform speaking, therefore I am opposed to it."

In 1885 Arkansas sent two women as delegates to the Southern Baptist Convention. It was the mission of these two women, little as they anticipated it, to change the constitution of the Convention. The word "brethren" was substituted for the word "members" because the men were fearful that the women would take the lead in matters which were men's concern. The two women were not recelved as delegates and women were received into the Southern

1. Cox, Ethleen B., Op. Cit., p.53

2. Heck, F.E.S., op. Cit., p.IIO 
Baptist Convention meetings only as visitors until 1922 when they were accorded privileges as delegates. I

Iontgonery, Alabama, was the Convention city in 1886. The women met again. The reports which wore received from ten states vere encouraging. Gifts amounted to over $\$ 20,000$. In 1887 the Convention met in Louisville, Kentucky. Mrs. Bagby of Brazil addressed the meeting of women. The women would have organized this year but they could not because the were not duly appointed delegates. However, two resolutions were passed which were steps toward organization.

"1. That a committee be appointed to request the Central Committees of the several states, each to appoint three ladies as delegates to neet during the next session of the Southern Baptist Convention to decide upon the advisability of organizing a general committee.

"2. That a Committee of Secretaries of the Central Committees be appointed to confer with the Central Committee of the state in which the Convention shall be held to select a presiding officer and secretary and arrange the programme for the meeting."2

Thus was the stage set for 1888 and the birth of the Woman's lissionary Union, Southern Baptist Convention.

7. See below, 85

2. Broadus, Eliza, op. Cit., p.4 
III

THE SUMHONS TO A GREAT TASK 
III

THE SUMYNS TO A GREAT TASK 1888-1908

I ORGANIZARION

a- Place, Date

b- Delegates and State Representatives

$c-$ Name and officers

d- Program

II THE WORK ESTPABIISHED
a- Constitution
$\mathrm{b}-$ Working Plan
c- Name
d- Christmas offering
e- Increasing Activities

III EVENTS OF THE FIRST DECADE
a- 1888 Christmas offering
b- 1889 Three Missionaries Sent Out by Offering
c- 1890 Alabama enters the Union Name is Chosen
d- 1891 North Carolina, Western Arkansas and the Indian Territory inter the Union
e- 1892 Celebration of the Centennial of Missions
f- 1894 Missionary Day in the Sunday Schools Started
6- 1895 Self-Denial Offering Started Bible Fund Inaugurated

IV EVIDENCES OF GRO NH

a- 1900 Home Board Church Building Fund Started Mountain Work Receiving Attention

b- 1901 Interest in Cuba Manifested

c- 1902 Missionary Appointed to the Indians

d- 1904 The Margaret Home Established Bible School in Louisville, Kentucky Opened

e- 1905 Visit to Mountain Schools by the Secretary

f- 1906 Literature Department Established Our Mission Field Launched

g- 1907 Woman's Missionary Union Training School Adopted

Mission Study Classes Started

Young Woman's Auxiliary Started 
II I

THE SUMMONS OF A GREAT TASK

Michael Angelo once said that there are great truth that pitch their shining tents outside our walls; and though but dimly seen there in the gray dawn, they will be manifest when the light widens into perfect day. Some great events pitched their tents outside the walls during this decade of Woman's Missionary Union history. They were dimly realized at first but became more and more manifest as the light widened into day. A new day was already flushing the horizon with its lines of red and gold.

The south again was coming into her own after long struggles with poverty and disaster. Southern hills were giving up their mineral wealth, Southern schools were broadening, Southern culture and Southern states were realizing their educations obligations to the negroes. With the coming of a new century a new South had grown up upon the deep foundations of the old.

\section{ORGANIZATI ON}

PLACE AND The basement of Broad Street Methodist DATE church in Richmond, Virginia, furnished the setting for the historical drama of the organization of one of the great forces in the missionary movement. 
Careless songs had died from the lips of Southern women. Rose colored dreams for their daughters had faded into the stern realities of life. The girl of 1830 was now a woman past her prime. She had witnessed many changes. She had gained in poise and influence. Thirty-two women from twelve states met on Friday, May 11, 1888, at 10 A.M. Miss McIntosh of South Carolina had charge of the program. Mrs. Theodore Witfield of Richmond, Virginia, presided. Miss Agnes Osborne of Kentucky acted as Secretary. Already there were 1,206 organizations scattered over the South and these had given over $\$ 45,000$ in 1887 . The results of this session should ever wipe Friday from the black books of the most superstitious. On Monday, May 14, a second session was held and the resolution of 1887 was acted upon. DELEGATES The Central Cormittees of each state had been asked to choose delegates to the meeting in Richmond. The Central Comittees had been notified previous to the meeting that the purpose of the meeting was to discuss and vote upon a Central Organization which would unify the efforts of the various state Voman's Missionary Unions and the local organizations in states where the state organization had 
not been perfected. The delegites from ten states had been instructed to vote in favor of the organization. They were Arkansas, FIorida, Georgia, Kentucky, Iouisiana, Maryland, Missouri, South Carolina, Tennessee and Texas. Others were to join later. Virginia's delegates were present but could not vote their state into the organization. They were compelled to wait for readjustment of the standing of the women's organizations with the Virginia Baptist State Convention. Mississippi had been urged by the men of their state Convention to postpone their alignment. North Carolina had been instructed by the men of the North Carolina Convention not to join. NAlie The name under which these women were organized was "The Executive Committee of the Vornan's Missionary Societies, Southern Baptist Convention."I OFFICERS The officers elected were: President, Miss M. E. McIntosh, South Carolina; Corresponding Secretary, Miss Annie Armstrong, Maryland; Treasurer, lirs. J. F. Pullen, Naryland; Recording Secretary, Mrs. James Pollard, Maryland.

1. - "Report of the Richmond Meeting", Heathen Helper, June 1888, pp.5-6. 
Vice Presidents

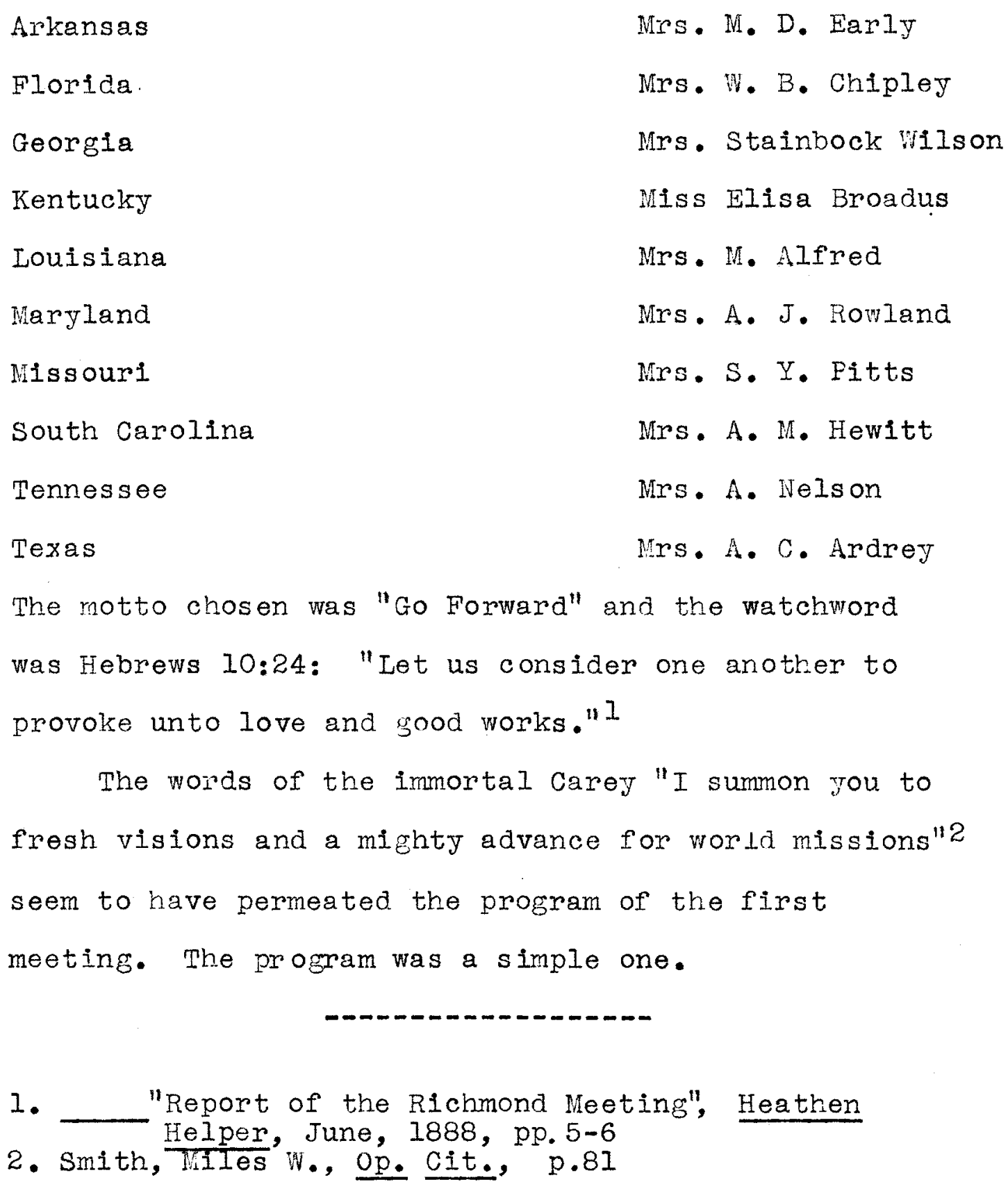


$P R O G R A M M E$

For

Woman's Meeting in Richmond, Va, in Connection With

Southorn Baptist Convention

$-\ldots 111-\cdots$

Broad St. H. E. Church

President, Mrs. Theodore Whitfield of Virginia

Secretary, Miss Agnes Osborne of Kentucky

Friday, May llth, 1888

10 A.M. Opening Exercises, Reading of Scripture and Prayer

10:15 A.M. $12 \mathrm{M}$. Organization of Woman's Work Paper by Mrs. John Stout of South Carolina to be followed by free interchange of views by representatives of the several states, after which the whole subject to be referred to a special committee for report on Monday.

12 M. 12:45 P.M. Statistical Report of Central Committees (Three to five minutes for each report)

12:45 P.if. 1:00 P.M. Special Obligation of Women to Spread the Gospel

Paper by Miss Alice Armstrong of Maryland

$$
\text { Monday, May } 14 \text { th, } 1888
$$

10:00 A. M. Opening Exercises

10:15 A. H. Report of Committee on Organization

11:15 A. M. Words from Missionary Ladies Present

Mrs. Graves of Canton, China

Mrs. Eager of Rome, Italy, and perhaps others. I

1. Anniversary Booklet, A Souvenir 


\section{THE WORK DSTABIISHED}

CONSTITUTION

ADAPTED
The Preamble of the Constitution was:

"We the women of the churches connected with the Southern Baptist Convention, desirous of stimulating the missionary spirit and the grace of giving among the women and children of the churches and aiding in collecting funds for missionary purposes to be disbursed by the Boards of the Southern Baptist Convention and disclaiming all intentions of independent action, organize and adopt the following constitution.

The twofold object of this Executive Committee shall be, first, to distribute missionary information and stimulate efforts through the state Central Committees where they exist and where they do not, encourage the organization of women and children in collecting and raising money for missions." I

No minutes were printed of this first meeting except

the partial record kept in the magazines "The Heathen Helper" and "The Baptist Basket."

WORKING "A three-fold cord is not quickly broken" said PLAN the writer of Ecclesiastes. From the first days of organized effort thero has beon a throe fold cord which has drawn women to higher attainment. It is composed of prayor, study and giving, of ten referred to as tho Woman's Missionary Union fundamentals. Prayer became interlocked with the missionary movement. Dr. S. D. Gordon said, "Let there be the quiet time when you go to meet God. Get alone daily with Him."2 The

1. Heck, F. E. S., Op. Cit., p.130

2. Gordon, S. D., Quiet TaIks on Prayer, p.37 
missionary method is "go ye," the means is "give ye", the motive is "love ye" and the might is "pray ye." The foundation stone of the new organization was that missionary information might be disseminated among women and children. This cardinal principle has never been changed, but has been enlarged upon. As women learned of mis ions the near-sightedness which kept them from seeing anything but the needs of their own neighborhood was being succeeded by a far-sightedness which is nearest the need. in some other community, so, linked with study was the ideal of service.

"Pigmies are pigmies still though perched on the Alps"l the poet says and in no realm is the truth truer than in that of missionary giving. The extent of the overflow determines the depth of the inflow. The emphasis upon giving dates back to 1872 when the appeal came for the support of a Bible woman in China. Thus when the organization took place one of the two reasons for united effort was the ideal of giving, "the desirability of raising missionary funds."

The first publication of the new Woman's Missionary Union was a pamphlet published in 1889 entitled "Sketch and Constitution of Woman's Missionary Union and Fields and work of Southern Baptist Convention." 2

1. Young, Edward, Night Thoughts, Night VI

2. Wharton, Mrs. W.H. Ready Pens for Willing Workers, p.14 
Page 38

"The first Annual Meeting of the Executive Committee of Woman's Mis ionary Societies (Auxiliary S.B.C.) was held in the First Presbyterian church, Memphis, Tennessee, May 11, 1889 at 10:00 A.M." Thirty-two pages of printed minutes presented reports, the president's address, the plan of work and other important items. Miss Annie Armstrong, the Secretary, said in her report "The first initial experimental year has passed. It is not a failure as the individual state reports will abundantly testify." I

The union had its headquarters on South Fayette Street, Baltimore, Maryland, in a corner room over the Baptist Book Store.2

NAME In 1890 each state was asked to suggest a name for the new organization. The name "Woman's Missionary Union" was suggested by Georgia. 3

CHRISTMAS In 1891 a special program was established OFFERING

in connection with the Christmas offering which had been inaugurated in 1888. It was fitting that a prayer season and Christmas Offering should be early linked. 1891 als o marks the introduction of the quarterly reports, the Union's system of gathering data.

1. Minutes of Annual Meeting, 1889, p.12

2. Wharton, Mrs.W.H.,Ready Pens for Willing Workers, p.19

3. Heck, F.E.S., Op. Cit., p.23 
These reports are in use today with slight change.1

The Centennial of william Carey's sailing for India was celebrated in 1892. Out of this grew the leek of Prayer for world misisions which gave added power to the Christmas offering.2

INCREASING "Like the little rill which takes its rise ACTIVITIES

in the mountains but gathers force until it waters the whole plain the Sunbeam Band began in a mountain town of Virginia and flowed out toward the great world for they were fain to water the plain where The dry fields burn and the mills are to turn, and a myriad of flowers mortally burn" 3 said Miss Heck in her report. This organization to which she referred is the missionary organization for small children (ages 4-8). The Woman's Mis'sionary Union adopted the Sunbeam Band in 1892 but the organization had its beginning back in 1886 in the heart of hrs. Ana ils om and her pastor, Dr. George Braxton Taylor. The first Sunbeam Band Class met in the corner of Fairmont church in Virginia and was led by Mrs. Els om.4

$$
\begin{aligned}
& \text { 1. Mallory, op. Cit., p.32 } \\
& \text { 2. Ibid., p.32 } \\
& \text { 3. Report of Annual lieeting, }, \frac{1892}{\text { Paths, p. } 24} \\
& \text { 4. Perry, Mrs.d.N., t.U.U. }
\end{aligned}
$$


$\mathrm{Pa}$

The Sunbeam Class began as a monthly meeting at which contributions were made, but $D_{r}$. Taylor felt that more important than money was the chlldren's knowledge of the world. He began to prepare programs. "Cousin George" as Dr. Ta: lor was affectionately called prepared the programs as an imaginary trip around the world with the children. These programs were printed in the Foreign Mission Journal in a Sunbeam Corner. The Foreign Mission board also bore the expense of printing the constitution and by-laws. Twice a year $D_{1}$. Tarlor arranged a Sunbeam Day for the public. 1

For eight "ears $D_{Y}$. Tarror had charge of the sunbeam work and more than 25,000 had been given in those years. The work had grom to such proportions that in 1892 it was thought wise to place the Sunbeam Band in charge of te Woman's Missionary Union. Soon after the adoption of this children's organization the states appointed state Sunbeam Leaders. Thus the first young people's organization was established as a part of the Woman's Missionary Union.

In 1895 came the introduction of the heek of Praver for Home Missions. This week was known as "Self-Denial Offering for Home Missions" but the title was gradually dropped because there was little real self-denial.

1. Vorld Comrades, Vol. XIV No. 8-May, 1936 
However the week of prayer and giving was continued. From the early days the jeek of Prayer for roreign Missions and the Neek of Prayer for Home Missions have been enthusiastically observed by women. The magazines were now beginning to give space in the pages for the news of the woman's vissionary Union activities. Both the Foreign Nission Journal and Our Home Fleld gave regular space to the Union. Two years later Kind words opened a missions department. The Secretary of Homan's Missionary Union became the editor of the Woman's Depertment in Our Home Fields and in Kind ords. 1 Columns in state papers were also devoted to the Woman's Missionary Union. The Christian Index of Georgia gave the full page to the women. The Union was publishing pamphlets of its own. Among them was "Ch1ps From Many Workshops." This was the first pamphlet on methods.

No estimate can be made of the far-reaching influence of one other event in this first decade. The Sunday School Board offered to give a dollar for every dollar the Union gave for the purpose of distributing Bibles. It was in this way that the Bible Fund grew

1. Wharton, lirs. H. Ready Pens for villing Workers, p.17 
up and it continued until 1935. One illustration serves to show the outreach of this phase of the work. A copy of the Bible purchased by this Fund fell into the hands of Edward Lara, the owner of a ranch in Mexico. Later he heard of a missionary, Dr. Powell, who was teaching the same book and invited Dr. Powell to visit his ranch and instruct $\mathrm{him}$. The result was the baptism of Iara and several others and the organization of two churches, one at $S a n$ Rafael and another at $S_{a n}$ Joaquin.

During this first decade eighteen new state organizations had come into being, three presidents had served, Miss M. E. McIntosh 1888-1891, Miss F. E. S. Heck 18921893, 1895-1898, and Mrs. A. M. Gwalthney 1894. The women had given $\$ 468,859.23$. No separate report of operating expenses was kept during the early years. The table of gifts shows liberality:

CONTRIBUTIONS FOR THE DECADE 1888 - 1898

\begin{tabular}{lccc} 
Year & Foreign Missions & Home Missions & \multicolumn{1}{c}{ Total } \\
1889 & $\$ 11,716.28$ & $\$ 12,057.41$ & $\$ 30,773.69$ \\
1890 & $21,398.66$ & $10,161.75$ & $31,560.41$ \\
1891 & $23,761.31$ & $15,229.03$ & $38,990.34$ \\
1892 & $25,040.27$ & $19,242.53$ & $44,282.80$ \\
1893 & $36,052.78$ & $26,283.97$ & $62,336.75$ \\
1894 & $23,514.09$ & $21,613.60$ & $45,128.59$ \\
1895 & $24,933.64$ & $23,515.61$ & $48,449.25$ \\
1896 & $22,799.55$ & $33,542.64$ & $56,342.19$ \\
1897 & $23,476.33$ & $10,841.05$ & $34,317.38$ \\
1898 & $21,633.51$ & $11,283.32$ & $33,395.43$
\end{tabular}


Page 43

We rejoice in the pioneering spirit of the early missionary hearted women who went forward in faith and blazedva trail. As we close this brief sketch of this decade of Woman's Missionary Union history we realize that much is left untold, though the decade may be marked off we cannot place boundary lines to events once set in motion.

\section{EVIDENCES OF GROWTH}

CHURCH BUILDING 1900 brought a new task to the LOAN FUND

$$
\text { attention of the women. As Home }
$$

Mission work expanded an increased number of churches were without buildings. A woman's heart responded to the need by a gift of \$3,500 which established the Church Building Loan Fund. After ten years the fund was increased by an additional gift of \$20,000 from the Woman's Missionary Union.

Early in the decade women began to respond to the call of mission needs in sections of the home territory. Over three and one half miliion people were in the mountain sections. In 1900 North Carolina Woman's Missionary Union made a call for volunteers for mountain teachers. Fifty went in answer to this need. 1

1. Withoft, Mabel Swartz, Oak and Laurel, p.31 
CUBAN VORK
In 1902 when the republic was established in Cuba there followed the separation of church and state and Baptist work began to expand. The Cardenas church is a monument to the increasing intorest of women in Missionary Societies. I

INDIAN IISS IONARY
A new feature was introduced into the work in 1902. The girls of Virginia undertook to support a newly appointed missionary of the Home Board to Indian Territory. This was the first concert of action on the part of girls for any definite object.? Prior to this Miss Armstrong, the Secretary, had visited the Indian Territory and oklahoma Territory. She was instrumental in inaugurating vork among the osages and Creeks. 3

MARGARET HOINE

The year 1904 marks two significant events. IIrs. Frank Chambers of New York gave to the Woman's Missionary Union a gift of 10,000 in honor of her nother, Mrs. Margaret valler. This gift was to be used to purchase a hone for the use of the sons and daughters of missionaries, and also for the use of missionaries on furlough.

1. Lawrence, Una Roberts, Home Hission Trails, p.43 2. Wharton, irs. H. H., Fruits of the Years, p. 37 3. Ibid., p 39 
The gift was accepted and the purchase of a home in Greenville, South Carolina was made on November 19, 1905. ${ }^{1}$ Three sons of Brazilian missionaries were the first beneficiaries. Another decade was to witness the sale of the home and the setting up of a trust fund in its place.2

BIBLE The second significant event of 1904 was the SCHOOL opening of a Bible school for women, in Louisville, Kentucky. It opened with four students, Rena Groover, Georgia; Ella Jeter, Oklahoma; Alice Huey, Alabama and Clemie Ford, Tennessee.3 The beginning of the school goes back to 1884-1885 when a girl from Virginia appeared in the classroom of the Southern Baptist Theological Seminary wanting Bible training. In 1889 Dr. E. Z. Simmons of China brought a report to Baptists in which he reminded them that the work of foreign missions requires religious education for women and that there should be a school for training of women who had been called to work just as there is the seminary for the training of young men. This report

1. Margaret Fund Pamphlet, p.2

2. Ibid., $p_{\bullet} 4$ -

3. Mullins, Mrs. E. Y., House Beautiful, p.16 
caught fire in the heart of Miss Eliza Broadus of Louisville, Kentucky. She consulted her pastor and a mass meeting was called on a Sunday evening in 1902 at the Fourth Avenue Baptist church. The result of the meeting was the apointment of a cormittee to consider what should be done. The committee consisted of six women: Miss Eliza Broadus, Mrs. S. E. Woody, Mrs. V. J. McGlothlin, Mrs. Arch C. Cree, Mrs. Trevor Wayne and Miss Fannie Moses. I The first money for the school was Given by Misses Mattie and Lucy Norton and a sister, Mrs. Minnie Norton Caldwell.

MOUNTAIN The year 1905 was a steadying year. The WORK Secretary, Miss Armstrong visited ten mountain schools in North Carolina, Tennessee and Kentuclxy and made preparation for the events of 1906 . IIPERATURE One of the most important Departments DEPARTMUNT of the work, the Iiterature Department, came into being in 1906. However, one must go back several years to really find the roots of the literature Department. Its beginning centered in a fund created by the Maryland Association in October 1889 for a Bureau of Information. The Bureau was set up as a

1. Mullins, E. I., op. Cit., p.16 
Missionary Library and Reading Room. Magazines and leaflets dealing with the work being done on all mission fields were kept in the Bureau's headquarters and were sold at a nominal price. The Woman's Missionary Society of Maryland was invited by the Maryland Association to cooperate in this effort. After the Woman's Missionary Union, Southern Baptist Convention was organized its headquarters office was in the same room with the Missionary Reading Room. In 1906 it was thought that the work carried on by the Bureau of Information could be handled by the new Union. After a period of adjustment the Maryland Association turned over to the Woman's Missionary Union the amount of endowment of the Maryland Missionary Room for the founding of the Woman's Missionary Union Literature Department. ${ }^{1}$ A gift of $\$ 1,402$ was made in 1906 for the distribution of missionary literature. With the addition of this sum the Literature Department was organized. During the first year 320,000 leaflets were distributed. In addition the Brick Cards for the building of the Cuban Chapel, the Missionary Topic Prayer Cards, Mission Programs, envelopes for mission offerings and many other things were printed.2

1. Wharton, Mrs. H.M., Ready Pens for Willing Workers, p. 19

2. Mallory, Kathleen, op. Cit., p.198 
MAGAZINES By 1906 1t was felt that the Union could best be served by a magazine of 1 ts own so Uur Mission Flolds was launched as a quarterly. The first issue was published in 1907. This was the first Union Official magazine which carried a program section with materials definitely designed to be presented at the meetings of Misiionary Socleties. It continued until the year 1914 when it was supplanted by Royal Serv1ce. ${ }^{1}$

The Boards of the Convention were recognizing the power and influence of this comparatively new organization. The Home Board's report for 1906 called attention to the fact that the work of the Woman's Missionary Union had gone forward with steady progress. It also commended the women for having heartily accepted the various recommendations of the Board and for having pursued their work with increasing intelligence and consecration. "In the dissemination of literature our sisters have rendered the Board most helpful assistance." 2 The report further sald that the women were largely responsible for bringing the subscription to The Home Field up to 30,000 .

1. Wharton, Mrs. H.M., Ready Pens for Willing Workers, p.23

2. Home Board Report, 1906, p.28 
The very first direct appeal to the Woman's Missionary Union for help from a native Christian was made in 1906. It came from a Chinese pastor. Each year since 1899 the Union had received yearly greetings from the appointed missionaries but never before from a native.1

Reports record one cloud in the sky of 1906. Miss Armstrong, the Secretary since the organization began, resigned her work. This was a distinct loss to the Union and to the missionary cause. However, with the coming of 1907 the light of a new day dawned, for while Miss Armstrong was no longer the Secretary, yet her counsel and influence were still at the disposal of the Union. TRAINING In 1907 the Training School which had SCHOOL

$$
\text { been opened in a rented building in }
$$

Louisville was adopted by the Woman's Missionary Union and thus came into full dignity. Following the adoption a house was bought. It was located at Preston Street and Broadway, Louisville. A school faculty was chosen with Mrs. Maude R. Mclure as principal. The school opened October 2, 1907. The formal opening

1. White, Blanche, Saved to Serve, p. 13 
was held in Broadway Baptist church with Dr. E.Y. Mullins presiding. ${ }^{1}$ on the opening day the Sunday School Board through Dr. J.M. Frost the Secretary, presented a gift of $\$ 20,000$, the cost of the entire building. Thirtyeight students from thirteen states matriculated this first year of official operation.

MISSION Likewise significant in 1907 were the first STUDY mission study classes. One of the most farreaching results of the Ecumenical Missionary Conference held in New York in 1900 was the organization of the Central Committee on United Study of Foreign Missions, which cormittee grew out of the women's meeting on that occasion. The Union worked with the Educational Secretary of the Foreign Mission Board. In 1907 and each Jear thereafter mission study classes were recormended for each Missionary Society by the Executive Cormittee of the Woman's Missionary Union, S.B.C. In 1911 the Standard of Excellence was adopted. This was a specified number of goals toward which each society would strive, the attainment of which classified the Society as Standard. The Mission study recomendation has been included annually in these goals which means that each Missionary Society attaining recognition as standard is required to have

1. Mullins, Mrs. E.I., Op. Cit., p.29 
mission study classes.

The Union was born in prayer and from the beginning had been $b$ ound together by prayer. The members had been drawn together by the monthly missionary "Topic Card" but the need for a closer coalition was felt and in 1907 the women recommended in the Annual Convention a daily Calendar of Prayer. Today the Calendar of Prayer appears monthly in Royal Service.

A special campaign of Enlistment took place during 1907. The response was gratifying but the Executive Committee sought to make enlistment a permanent phase of the work. An Enlistment Department w as established and Enlistment became one of the chief aims. This was also a year in which a new Secretary, Miss Edith Crane, was elected. At this time the position of Secretary was made a salaried office. The reports do not give the amounts of salary or expenses but only list the gifts to missions. YOUNG WOMAN'S A Rehearsal of 1907 would not be comAUXILIARY plete without the mention of the organization of the Young Woman's Auxiliary. "Iike motherlike daughter" is a Scriptural proverb. A beautiful application of this is found in the way in which Southern Baptist women led young women to unite with the Young Woman's Auxiliary. Back as far as 1888 there were, 
over the South, several missionary societies for young women. In the minutes of the General Association of Kentucky Baptists from 1893 to 1906 mention is made of several gifts from the Young Ladies Band, Mayfield, Kentucky.l All along they were an integral part of the Woman's Missionary Union but not until 1907 did they really take on a uniform name. The name had been presented by Alabama. The watchword, Daniel 12:3 "They that be wise shall shine as the brightness of the firmament and they that turn many to righteousness as the stars forever and ever", was suggested by Virginia. With the perfecting of the Young Woman's Auxiliary the second of the missionary organizations for young people fostered by the Woman's Missionary Union was incorporated into the working plan. This provided for young women between seventeen and twenty-five.

In 1907 also the Tichenor Memorial Fund of $\$ 20,000$ for the Church Building Loan Fund was completed. This Fund, we recall, was started in 1900 by a gift of $\$ 3,500$ by a woman. The Christmas offering increased by $\$ 35,000$ during this year.

1. Perry, Mrs. E. N., W.M.U. Paths, p. 17 


\section{CONTRIBUTIONS FOR THE DECADE 1899 - 1908}

\begin{tabular}{|c|c|c|c|c|}
\hline ear & $\begin{array}{l}\text { Foreign } \\
\text { Missions }\end{array}$ & $\begin{array}{c}\text { Home } \\
\text { Missions }\end{array}$ & $\begin{array}{l}\text { Bible } \\
\text { Fund }\end{array}$ & Total \\
\hline $\begin{array}{r}902 \\
903 \\
904 \\
905 \\
906 \\
907 \\
908\end{array}$ & $\begin{array}{l}\$ 24,152.92 \\
31,757.65 \\
31,801.31 \\
34,787.17 \\
36,852.57 \\
47,777.82 \\
53,678.45 \\
62,719.770 \\
74,744.28 \\
87,515.15\end{array}$ & $\begin{array}{l}14,129.67 \\
18,114.13 \\
20,549.54 \\
19,510.48 \\
19,295.38 \\
24,869.70 \\
30,698.70 \\
37,391.50 \\
48,027.01 \\
56,190.70\end{array}$ & $\begin{array}{r}280.10 \\
1,364.42 \\
622.42 \\
478.87 \\
255.85 \\
443.24 \\
417.55 \\
304.10 \\
516.66 \\
1,560.88\end{array}$ & $\begin{array}{r}38,562.69 \\
51,236.20 \\
52,973.27 \\
54,776.52 \\
56,403.80 \\
73,090.76 \\
95,294.32 \\
103,601.90 \\
125,124.04 \\
186,198.58\end{array}$ \\
\hline
\end{tabular}

These figures include the following:

Margaret Fund

The Jear 1907 was one of great progress, but even more was to come. No one walks along God's paths without being willing to turn into new and larger ways. This decade was a prelude to a decade of additional golden events. 
A DECADE OF GOLDEN EVENTS 
A DECADE OF GOIDEN EVENTS 1908 - 1918

I THE ROMANCE OF A DECADE

a- Work for Young People

b- Foreign Mational Woman's Missionary Unions

c- New State Unions affiliate with W. M. U.

d- Rural Emphasis.

e- Publications

II FAR REACHING EVENTS

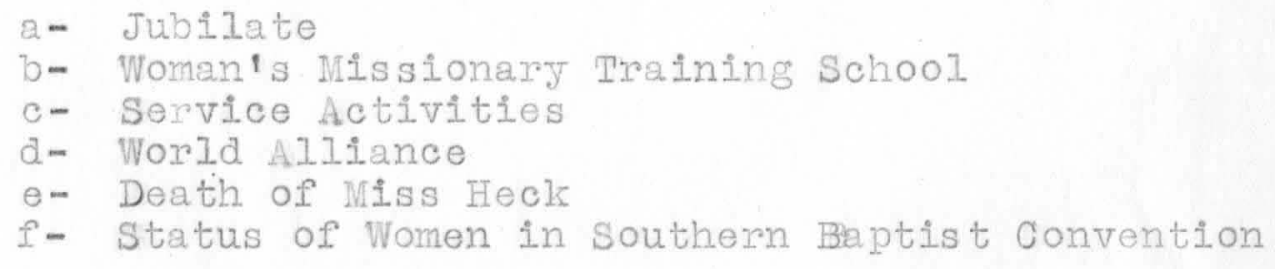

II I A CHAIN OF GOLDEN EVENTS

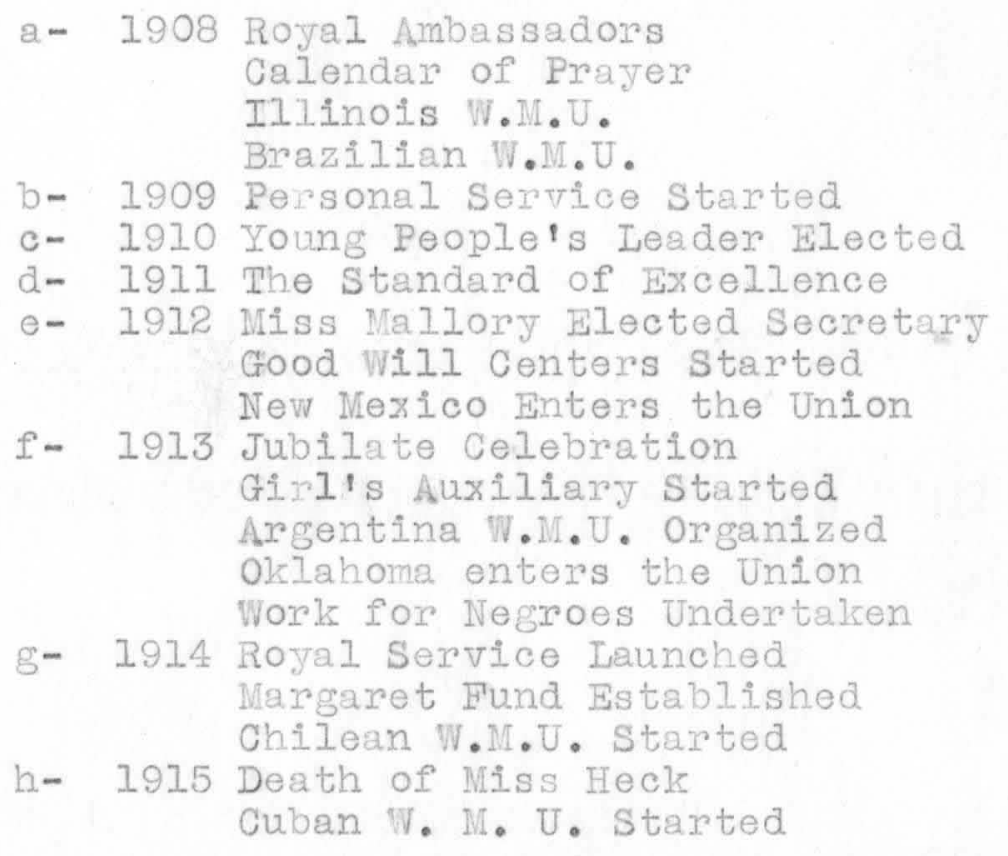


i- 1916 Mrs. W. C. James Elected President

j- 1917 W. M. U. Training School Built

k- 1918 Lottie Moon Christmas Offering Named Mexican W. M. U. Organized 
IV

A DECADE OF GOLDEN EVENTS

The Jears 1908 - 1918 were years pregnant with possibilities that were to become glowing realities. The Woman's Missionary Union seemed destined to be responsible for many fine things during this decade. The years were like a chain of golden events and Walt Whitman's remark that if History were rightly told there would be no need for romance seems particularly true of this decade which was so prolific in new rorms of Missionary endeavor.

IHE ROTLANCE OF A DECADE

This important period opens under the direction of a new Secretary, Miss Edith Crane, and a new president, Miss F. E. S. Heck. ROYAI Before Miss Heck was made president she AIBASSADORS had been made chairman of a committee on Mission work for boys. Miss Heck's bellef in the possibilities of boys' work led her to begin to make definite plans for the boys. Since the adoption of the Sunbeam Band and the establishment of the Young Woman's Auxiliary for girls and young women the young 
people's work had been considered a part of Woman's Missionary Union and not an appendage. Archimedes once said that he could lift the forld if he could find a point on which to rest his lever. The Woman's Missionary Union seemed to feel that chilahood is that strategic point. The current of humanity is constantly refreshed with the stream of youth. Socrates gave utterance to his belief in youth when he expressed tho desire to climb to the highest point in Athens and lift his voice and proclaim "Why do you turn and scrape every stone to gather wealth and take so little care of the children to whom you must one day relinquish a.11?" This was a question which women were beginning to ask themselves. For a time there was no provision for boys in the missionary education system. Some remained in the sunbeam Band but more left the organization when they reached the age of ten and drifted away from missionary activities. It seemed timely that at the Annual Meoting in May, 1908, Miss Heck should make the following report: "Your committee on Mission work for boys begs leave to submit the following recommendations:

1. That the Woman's Missionary Union take in hand and press the organization of missionary socleties for boys.

2. That the general name of this organization be the order of Royal Ambassadors and that 
the organization have a constitution, motto, and pin." I

The Convention accepted the report and thus decided to include boys in their missionary program. The name had suggested Itself to Miss Heck while she was listening to the hymn "The KIng's Business", which later became the Royal Ambassador song. Among the earliest chapters were chapters in Goldsboro, North Carolina; Owensboro, Winchester, Parkland, Newport, and Frankfort, Kentucky. This Department of work has experience phenomenal growth. Today there are 4,355 chapters enrolling 42,700 boys. 2 GIRL'S AUXILIARY

At the Jubilate meeting in 1913 in st. Louis, Missouri, a cormittee on Work Among Younger Girls was set up. A report was made the following year, which report recommended the Girl's Auxiliary. Through all the growth of the missionary work has run the golden life of young people. The girls were alert to do whatever they were directed to do. The report charged each Missionary society with the responsibility of enlisting girls twelve years and up in missionar. endeavor. Already thirty-eight organizations were reported. In another year a pin with the five pointed star and the interwoven letters, G. A.

1. Minutes of the Annual Meeting, 1908

2. Report of Young People's Secretary, 1938, p.2 
was adopted. Also a hymn, "Wo've a Story to Tell to the Nations" and the watchword, Isaiah 60: 1 were accepted. As the last chapter will show, no organization has had such phenomenal growth as this one.

Another phase of the work which recelved some attention was the work among college students. COLLEGE With every passing jear the work grew Y.W.A. steadily and the demands and needs of the work enlarged as well. A College Correspondent, Miss Susan Bancroft Tyler, now Mrs. Curtis Lee Laws, was appointed. The title does not indicate the work which was hers for she was a Traveling College Secretary in reality. In the appointment the Convention said that attention should be given to colleges and boarding schools. "The college girls' problem becomes very acute. They are the very flower of our young womanhood."I While 1910 marks the officlat organization of the college young Woman's Auxiliary, there were many organizations prior to this date. Juds on College, Alabama had an organization in 1838. The missionary society was founded almost as soon as the school was established.

1. Heck, F. E. S., Op. Cit., p.215 
Hollins College had an organization in 1842, Bessie Tift College in 1847, Greenville College in 1854, Richmond Woman's College in 1854. The latter deserves special mention because it came into existence as an endowed organization. A $\$ 1000$ gift was made to the missionary society of Richmond Female Institute to be in perpetual trust, the interest to be used for the purchase of mission books and magazines.1 YOUNG PEOPLE'S At the Convention meeting in Houston, SECRETARY

$$
\text { Texas in } 1915 \text { further plans were }
$$

made for extending the missionary work among young people. Provision was made for the final link in the full-graded missionary organization through the following motion:

"That a Y.W.A. be organized in every one of our Baptist schools and hospitals in order that young life and service of our students may be conserved for Christ and their church in God given channels of usefulness. ${ }^{112}$

At this convention Miss Mary Fais on Dixon was elected Young People's Secretary with the responsibility of promoting mission work among college girls and nurses as well as among the young children.

1. Silver Anniversary Booklet, p.6

2. Minutes of Annual Meeting, $1916, \quad p_{.14}$ 


\section{FOREIGN 许. U.}

This is the period which marks the birth of several National Wornan's Missionary Unions. BRAZILIAN U.M.U. The first Foreign Woman's Missionary Union was organized in Brazil in 1900. This Union was the result of the growth wich had come from the first women's society which had been organized in the First church in Rio in 1889. The first president was Mrs. Grace Entzminger. For eighteen vears these women carried on without an office except a room in a home for storing literature and records. Headquarters continued in a hone until 1926 when the office was moved to the Carroll Memorial Publishing House. CHINA The year 1910 goes down indelibly in mission H. U. history for in this year the China Woman's Missionary Union was organized. There were women's societies in many sections of China. Those in SooSung-Sin were the first to come together in a Federation. Miss Villie Kelly, Mrs. R. T. Bryan, liss Lottie Price, Mrs. Zee and Mrs. Lui were the guiding spirits. ${ }^{1}$ ARGENTINA In Argentina the women were twent-two Jears U.M. U. later in having help than were their sisters in Brazil and

1. White, Blanche, op. Cit., p. 56 
the rapid accomplishments of the Argentine women is a miracle indeed. The Argentine Woman's Missionary Union was organized in 1913 with six societies. CHILE Another Foreign Woman's Missionary Union had W.M.U. its beginning in 1914. The first Chilean missionary society for women was organized by a native pastor who had gone to the Seminary in Brazil. This society was started before the missionaries had even reached Chile.

CUBA The organization of these national Missionary $\mathrm{W} \cdot \mathrm{N} \cdot \mathrm{U} \cdot$

$$
\text { Unions gave impetus to Cuba and the year } 1915
$$

finds Cuban women uniting in a Cuban Woman's Missionary Union. The Mexican women followed the example of the Cuban women and organized in 1918. 1

NEW STATE The work not only in the foreign field UNI ONS AFFILIATE but likewise in the homeland was becoming more unified. The year 1908 marks the entrance of Illinois into the Southern Woman's Missionary Union. Two other state Unions were to affiliate with the Southern organization during this decade, namely New Mexico in 1912 and Oklahoma in 1913. With the affiliation of these two all the Southern States

1. Lackey, Margaret, W.M.U. Service, p.43 
except Arizona are united in the one organization. RURAL EMPHASIS Before this decade closed emphasis was being given to the development of missionary activities in the rural areas. The Woman's inissionary Union became conscious of the need of such emphasis as a result of a study which showed that five-sixths of Southern Baptists live in the countr. What became known as the Circle Plan was developed to meet the need in rural areas where transportation was a problem. This plan provided for a geographical grouping of the members of the Missionary Society. Each week the women of a particular locality would meet together and once a month the women composing the Circles would all meet together at the church. This plan was really to have two, three or four, as the community needs demanded, small Societies within the Hissionary Society. Later this plan was likewise adopted by city churches, many of which used the circle Plan for a geographical division, others who used it for age grouping and still others used it for groupings for greater participation on the part of a greater number of individuals. This Circle Plan also provided for the Home Department. This de- 
rartment or Circle was composed of memcers who wre invalids, shut-ins or women who were confined to the house. They studied the mission books, secured the publications, made their contributions and rarticipated in the vork in every way except attendance. This method of work, the Circle plan, was put into efiect in 1917 and is still the method "sed.

\section{PTBIICATIONS}

ROYAL The decade is marked by the exransion SERVICE of the work in many directions. Ixranding worls demanded literature. Answering this need the Annual leeting in 1914 recommended that Our Mission Fields be issued as a thirty-two rage monthly magazine and the name be chaned to Roval. Service. 1

It was suggeste that the missionary program for each grade of societies, news from all the f'ields and departments of work be included. "Type is lifeless, raper is a non-concuctor. but the printed pree is a thing of $1 i e .42$

In september, 1914, the first iscue was sent out. The subscription list was 15,000 . By hay,

1. Wharton, rrs. E. R. Ready Tens for Wiline Worlers p. 19

2. Ibid. p. II 
1915, the list had jumped to $21,000$.

The history of the Woman's Missionary Union magazines which led up to the Royal Service is worthy of note. The Heathen Helper for the women's societies of the South was published in 1882 by the Central Committee of Kentucky. Its first issue carried articles by Lottie Moon, Lula Whilden and Dr. R. H. Graves. The Baptist Basket succeeded the Heathen Helper in 1888. Mrs. Thomas Osborne was the editor. Fourteen states had co-editors, but the magazine was still published by Kentucky. Our Mission Field, edited by Miss Fannie Heck, beginning in 1907 was the first magazine published by the Woman's Missionary Union. In 1914 this magazine was renamed Royal Service and was under that title edited by Mrs. Nimmo of Baltimore, until 1920 when Miss Kathleen Mallory became the editor. CALENDAR The Calendar of Prayer which by the close OF PRAY of the decade had become a regular department in Royal Service was at first a separate publication. The Calendar of Prayer instituted in 1908 had its beginning back in Baltimore in 1884. At the 1885 Convention in Augusta, Georgia, Dr. Wilson read the following to the Woman's meeting. "One year ago in 
an upper room in Baltimore during the Southern Baptist Convention three Baptist women after a season of prayer covenanted to pray and ask the sisters of all the Southern states to pray on the morning of the first Sabbath in each month for God's blessing on Woman's missionary work and the work of our missionaries. Two of the ladies are here today and ask their sisters to renew the covenant for the next year."I Each year the women covenanted in such fashion until 1908 when the Prayer Calendar supplanted the covenant. This calendar was a small pamphlet carrying the objects for daily prayer. By 1918 this was included in Royal Service. MANUAL OF Counselors for the young people's METHODS

$$
\text { organizations were in need of training }
$$

for leadership. To meet this need a correspondence Course was planned. It was prepared first for Girl's Auxiliary Counselors but was later enlarged to include the other organizations. It was a course on methods of work and was published in mimeograph form. The W.M.U. Manual of Methods was written for leaders of Woman's Societies. The two courses of study formed the basis

1. Broadus, Eliza, Op. Cit., p.3 
for the prescribed courses in mission study which followed later.1

STANDARD OF Up to 1911 organizations in the churches EXCEILENCE

sent reports of the work done to the State office or the State Central Committee but there were no specific goals, no method of measuring the work of the organization or of encouraging concerted action or special phases of the work. In 1911 a standard of values was adopted. It was known as a standard of Excellence. It set up twelve objectives toward which each organization was asked to work during the year. It was a step towards rounding out the missionary program instead of having societies work for a whole year studying or emphasizing just one phase of the work. It included goals for mission study, for giving, for observance of the weeks of prayer, for enlistment, for attendance, and service activities. 2

An important committee was appointed at the Annual Meeting held in Asheville, North Carolina in 1916. The committee was composed of a member from each state and was assigned the task of studying the status of mission

1. Bucy, Wilma, Op. Cit., p.52

2. Mallory, Kathleen, Op. Cit., p.144 
study in the organizations. When the committee reported back it recommended:

1. A superinterdent of mission study for each state.

2. Normal mission study teachers.

3. At least one book on home and forelgn missions to be studied. 1

By 1918 several bo: ks had been prepared and a definite course in mission study was incorporated in the Plan of Hork. The course included a Bible Study book, All the World In All the Word; Stewardship and Mission; Talks on Soul-Winning; One Foreign and One Home book, and The Manual of N.M.U. Certificates and seals were printed and were used as the official recognition for the prescribed study.

\section{FAR REACHING HVENTS}

JUBILATE No event in the history of the woman's lissionary Union was more far reaching, than the celebration of the Jubllate because of the renewed emphasis on missi:ns and the outgrowth of the preparation for the celebration. A new Secretary, Misis Kathleen Mallory, was elected in 1912 on the eve of the twentyflfth anniversary. Imrediately she was called upon to work with the committee on the plans for the Jubilate.

1. Lackey, Nargaret, op. Cit, , p.63 
The celebration took place in Saint Louis in 1913 on May the eighteenth. Remarkable growth had been made during the twenty-five years of the life of the organization. The attendance in saint Louis was 1,419. The president's address was on Efficiency. The watchword was Psalm 100:2 and the hymn was "Joy to the World". This was the first official hymn ever chosen by the Woman's Missionary Union. Each year since that time a special hymn has been selected. Mrs. W.C. James chalred the Jubilate Committee. The women pleiger $\$ 350,000$ to help in the million dollar Church Building Loan Fund of the Home Mision Board. In the secretary's report we read:

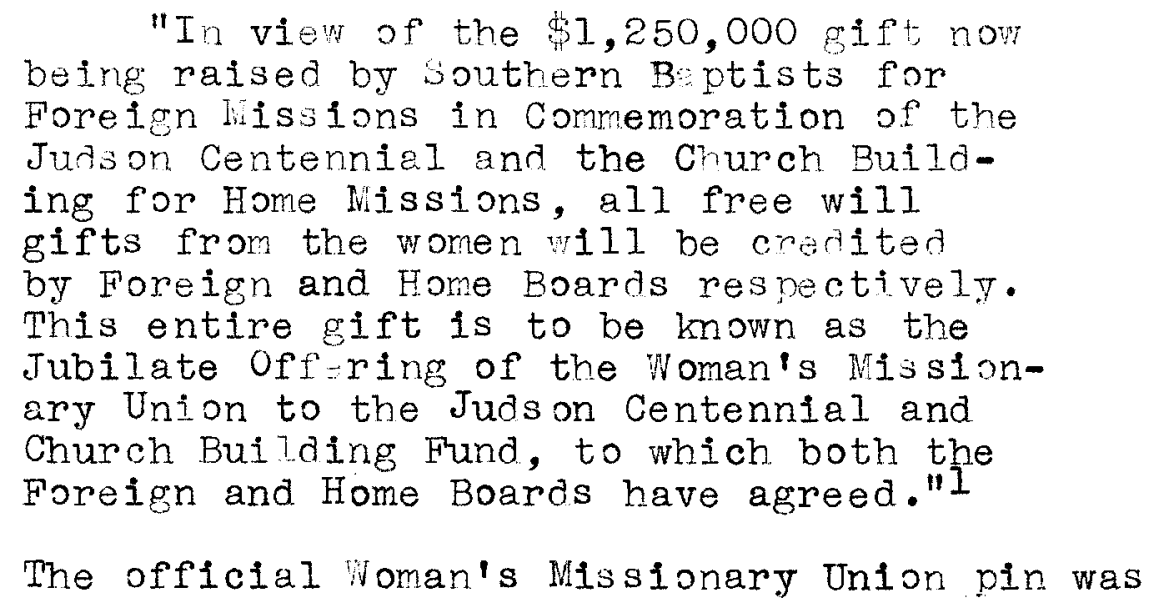
designed by Miss Emra Whitfield of Richmond, Virginia whose mother presided when the Union was organized in 1888. There is special significance in the pin. 1. Report of Executive Secretary, 1913, p.14 
The shape represents a double fish head. In the early days of Christianity followers were persecuted, so they strove to hide their faith from all except friends. They would make the mark of a fish head when meeting another. If the person met were a Christian, he, too, would make a fish head. The letters which make up the word for fish in the Greek (I-XOVS) are the first letters of the words "Jesus Christ God's Son, Savior". Around the border of the pin 1 s inscribed "Woman's Missionary Union, 3.R.C. 1888." In the center is an open Bible with the Union's watchword engraved on it. The Bible rests upon the map of the world. Above the Bible is a flaming torch, the standard of which extends below the map.. ${ }^{1}$

Out of the Jubilate celebration came not only the pin but "In Royal Service" which later became a mission study book. Also the woman's hymn "Come Noman, Wide Proclaim" written by kiss Heck. A standard of values for all organizations was adopted, a permanent house for the Good ill Center was purchased, work was started with the Negro women. 2 These phases will be discussed later.

1. Nallory, Kathleen, op. Cit. p.63

2. Cox, ithleen B.: Op. Cit., p.68 
The Cuban Woman's Missionary Union to which attention has already been called, was also organized at this time, with seven societies.

Among the other achievements of the Jubilate was the organization of Girl's Auxiliaries for girls twelve years and $u p .1$

From the report we see that $\$ 381,319.77$ was given for various mission causes. It was the first year the Woman's Missionary Union had ever passed the three hundred thousand mark. 2 The real results of the celebration cannot be known by what occurred in the year 1913 but the achievements of the years which follow are a result of influences set in motion on this occasion. NEW TRAINING A resolution passed at the 1914 con$\mathrm{S}$ CHOOL vention was an outgrowth of the impetus of the Jubilate. This resolution was to enlarge the Woman's Missionary Union Training School. A goal of $\$ 75,000$ was taken to be raised within three Jears. This was to be used to erect a building as soon as possible. The Sunday School Board, ever a friend to the Training School, presented the Woman's Missionary Union Gonvention

1. See above, p.56

2. Minutes of Annual Meeting, 1938, pp.64-65 
with a gracious gift of $\$ 10,000$ for the enlargement of the school. This was the first gift on the $\$ 75,000$.

It will be recalled that the Sunday School Board through its Secretary had made a generous gift when the school was new and the first house was bought. I By the time the Convention met in New Orleans $\$ 61,789.41$ of the goal of $\$ 75,000$ had been reached. 2 There was great rejoicing when the convention instructed the building of a new Training School. On April 5, 1917, in all sorts of weather, the corner stone was laid for the building which now stands at the corner of preston Street and Broadway, Louisville, Kentucky. On May 22, 1918 the new Training School was dedicated. Mrs. George B. Eager presided. The first commencement was held in the Heck Memorial Chapel which was a gift in memory of Miss Fannie Heck who was serving the Woman's Missionary Union as its president at the time of her death. Twenty-two young women were graduated in this first service in the new chapel. The marble lobby was a gift in memory of

1. See above, p.50

2. Minutes of Annual Meeting, pp.64-65 
Dr. J.M. Frost, who was Secretary of the Sunday School Board at the time of the Board's initial gift to the school.1

\section{SERVICE ACTIVITIUS}

MARGARUT Conditions were changing on the mission FUND

fields as well as at home. It was decided

to sell the Margaret Home, a home for the sons and daughters of foreign missionaries, and invest the money in a Prust Fund, the interest of which was to be used for Scholarships for the college education of the sons and daughters of foreign missionaries. This was thought to be the wisest and most serviceable way of assisting the missionaries so the Nargaret Fund was created in $1914 .^{2}$ GOOD WILI On October 25, 1912, the first Good CENTER

W11] Center was started by the Woman's Missionary Union. There was a dual purpose in the establishment of this work. Community Centers, Settlement Houses, Nationality Houses, etc. were becoming the important agencies in the field of Social Service. The Board of Managers of the Training school felt that if young women were to be

1. Mullins, Mirs. E.Y., Op.,Cit., p. 59

2. Minutes of Annual Neeting,1938,pp.64-65 
adequately equipped they needed first hand information and experience in an establishment of this type. Furthermore, some of the larger missionary Societies were starting Community Centers on a small scale. The Woman's Missionary Union felt that if this phase of social service was to be encouraged it should provide a pattern for the work. The Good Will Center was located at 512 East Madison Street, Louisville, Kentucky, within easy reach of the Training School. It was also in the midst of a community made up mostly either of people of foreign background, or the lowwage group. The activities of the center were to be conducted entirely by students attending the "Noman's Missionary Union Praining School under the direction of a trained social worker.l

This settlement work is a definite part of the Personal Service work of the Woman's Missionary Union. Personal vervice is the term used for social service and church missions. It was a golden event when Personal Service was inaugurated in 1909. The newly established Department was placed in the hands of Mrs. H. Wharton who served for fourteen years.

1. Mullins, Mrs. E. Y., Op. Cit. P. 53 
NGGRO This Department is responsible not only for IORK

the Good Will Center work but sponsors also work among Negroes and foreign born groups. As a result of the Jubilate, Vienna Parker, a negro woman was employed to work among the Negro Women. She served until 1915 when the second and present worker, Betty ithers, another Negro, was appointed. The chief Iine along which the roman's lissionary Union has been of assistance has been furnishing literature for the Negro lissionary societies and furnishing teachers for the rision itudy classes. 1

FRENCH A part of the Mission work which is supervised SCHOOL by the Home lission Board is a service activity of the woman's Missionary Union. The Negro work with which the women help is one example of this. The mountain work where women maintain centers of activit $y$ is another and the French 3 chool is yet another. A part of Home riission work covers work with various foreign speaking groups. In Southern Iouisiana are to be found many French spaking people. It was evident that the most effective work could be done by the French people themselves. This necessitated education and training. A school, Acadia Academy, for training the

1. Wharton, Mrs. H. M. Fruits of the Years, F.56 
French speaking people was established in 1917. The Toman's Missionary Union was largely responsible for this school and its support.1

WORLD ALLIANCE The Woman's Missionary Union took part in the Missionary Jubilee held by women of all denominations in celebration of the Fiftieth Anniversary of the organization of the Union of Nissionary Societies in New York City. A second event of world wide reach was the Baptist Vorld Alliance meeting in Philadelphia in 1911. This brought together Baptists of the world. There was a special meeting of the Baptist women of the world. The President of the Noman's Missionary Union was spokeswoman for the women of the United States. The Secretary of the organization was chosen as Secretary of the noman's Committee of the Forld Alliance. The Voman's Missionary Union took its stand in all movements to unite women 12 DEATH OF It seemed doubly tragic that the outstandMISS HECK

ing leader and president should be lost in the midst of rapid growth and in days demanding wise foresight. The 1915 Convention met in Fouston, Texas. The president's message was dictated from a hospital

1. Lawrence, Una Roberts, Home Mission Trails: p. 44

2. Cox, Ethleen B.,op. Cit., p.59 
bed. It is one of the classics in Woman's Missionary Union literature and bears this heading "Hygeia Hospital, Richmond, Virginia, April 20, 1915." In part the message said:

"Be prayerful in your planning. $\mathrm{Be}$ patient and persistent in your fulfillment. Plan not for the year but for the years. Think long thoughts.

Train children for world-wide service.

Lead young women into places of joyous responsibilities.

Be gentle in your personal lives.

$\mathrm{Be}$ joyful knowing His purposes are good.

Bring all your power into the best service of the best King."I

Some of Miss Heck's admonitions became the charter for the development of certain phases of the Union's work.

The message was read by Mrs. F. S. Davis of Texas . Miss Heck was re-elected to the presidency, but she died on August 25, 1915.

In Miss Heck's period of service she had been an advocate of international peace. Among the first things of the 1915 Convention was a resolution which was sent to President Wilson. It is indicative of the Woman's Missionary Union's interest in peace. It is true that in a few years some of those very women had given their sons and husbands in war. They were thankful,

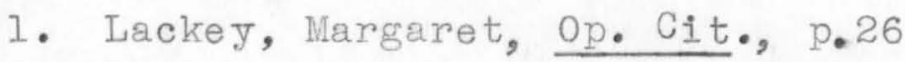


however, that they recorded their first desire to be peace. This body of women was the first religious body to take the step in sending such a resolution to President rilson.

MOTIONS CONSIDERED

An event which had far-reaching effect was the consideration of certain motions which were considered by the General Convention of Southern Baptists. The motions were introduced in the General Convention because of an action taken in 1885 by the Convention which changed the constitution of the convention to read "brethren" instead of "member", thus excluding wonen as voting nembers of the body. The motions now as introduced were of importance because they had to do with the status of women in the Southern Baptist Convention. The motions had to wait for five Tears for favorable action. The motions were:

"Whereas the women constitute so vital a part of the membership of our churches both in numbers and in workers and wheras the present wording of the constitution of the Southern Baptist Convention is such as to prohibit the recognition of women as messenger; Therefore be it resolved that Article III of the constitution be so altered as to read as follows: 'The convention shall consist of messengers by Baptist bodies contributing funds for the regular work of the Convention on the basis of one messenger for every $\$ 250$ actually paid into the treasury of the Boards during the fiscal year ending the thirtieth day of April next preceeding the new meeting of the Convention. 1 . 
Second: Your Committee feels that in as much as the Convention has appointed a Cormittee to report upon the matter of admitting women as delegates to this Convention and that some connection of the loman's Missionary Union with the Boards of the Convention would add to the efficiency of our work, we recommend, therefore, that this part of the report be referred to the Committee on Woman's Relations for their Consideration."I

It is a corment on the reluctance of the men to give women equal status that this motion waited until 1922 to be passed.

It is fitting that such a decade should close with the decision to include the Prayer Calendar in Royal Service, to change the name of the christnas offering to "Lottie Moon Christmas Offering for Foreign Missions" commemating the life of Lottie Moon who was responsible for its origin, and the inauguration of the third week of Prayer which is observed each October for state Missions. The introduction of this third week rounded. out the mission program for Home, Foreign and State Missions. The increase in the gifts of this period seems to substantiate the fact that it had been a decade of growth and achievement.

1. Minutes of the Southem Baptist Convention, 1917, p. 33 
CONTRIBUTIONS FOR THE DECADE 1908 - 1918

\begin{tabular}{llrl} 
Year & \multicolumn{1}{l}{ Foreign } & \multicolumn{1}{l}{ Home } & $\begin{array}{l}\text { Bible } \\
\text { Fund }\end{array}$ \\
1909 & $\$ 96,641.24$ & $\$ 57,369.65$ & $\$ 1,379.89$ \\
1910 & $123,216.16$ & $77,881.23$ & $1,340.63$ \\
1911 & $127,900.47$ & $83,850.15$ & $1,219.38$ \\
1912 & $156,846.41$ & $97,557.17$ & $1,574.87$ \\
1913 & $168,345.24$ & $105,613.25$ & $1,428.26$ \\
1914 & $246,326.41$ & $117,656.24$ & $1,532.25$ \\
1915 & $214,356.95$ & $114,097.43$ & $1,765.71$ \\
1916 & $253,581.27$ & $121,301.67$ & $1,258.71$ \\
1917 & $280,695.64$ & $129,947.07$ & $1,500.00$ \\
1918 & $251,226.63$ & $182,425.45$ & $1,671.15$
\end{tabular}

Year

1909

1910

1911

1912

1913

1914

1915

1916

1917

1918

\section{Margaret}

Fund

$$
\begin{array}{r}
\$ 1,427.82 \\
1,555.58 \\
1,389.49 \\
1,253.81 \\
1,219.00 \\
\hdashline 13.60 \\
787.89 \\
1,473.96 \\
1,919.54
\end{array}
$$

Training

School

$$
\begin{array}{r}
\$ 15,945.47 \\
11,965.94 \\
12,148.42 \\
10,724.99 \\
14,122.97 \\
15,804.87 \\
32,785.09 \\
29,004.32 \\
53,854.67 \\
67,569.97
\end{array}
$$

Total

$$
\begin{aligned}
& \$ 172,764.00 \\
& 215,959.54 \\
& 226,507.91 \\
& 267,957.25 \\
& 290,728.72 \\
& 381,319.77 \\
& 363,018.78 \\
& 405,933.86 \\
& 467,471.34 \\
& 504,812.741
\end{aligned}
$$

1. Annual Report of Woman's Missionary Union, 1938, pp. 64-65 
DAYS OF EXPANSION 


\section{$\mathrm{V}$}

DAYS OF EXPANSTON 1918 - 1928

I Expanding Lines of work

a- Development of Foreign National ork

Brazilian Y.i.A.

Nigerian, Japanese, Ilungarian and

Chilean . M. J.

b- Changes in Plans and Policies

Chan ges in Giving and 75 Milion Campaign

Headquarters hoved

Status for wornen and W. U.

c- New Ventures

Student, White Cross and Service Work

Y.W.A. Camp

New Workers Employed

II Women Leading the Way

a- Personal Service

b- Mission Study

c- Literature

d- Ruby Anniversary

III Expansion Year by Year

a- $\quad 191975$ Million Campaign

Brazilian Y.W.t. and Nigerian W.M.U. organized Post Graduate Mission study

b- 1920 Japan W.M.U. Organized

Student Activities

White Cross work

c- 1921 Headquarters lroved

Fork Among the Jews and Mountains

d- 1922 World Comrades Launched

Missionary Library Fund Started

Grace McBride Y.A.A. Emphasized

Women made Delegates to S.B.C.

e- 1923 Southwide Camp Started Constitution Changed

Literature Department Secretary Chosen

f- Chilean and Hungarian W.M.U. Organ

g- 1925 Training School Principal Changed

h- 1926 New Good Will Center Built

i- 1927 Ruby Anniversary Launched

$j-1928$ World Alliance Held

Ruby Anniversary Completed 
DAYS OT AXPASION $1918-1928$

It is difficult to separate the work of an organization into distinct periods for the flower of achievement of one decade reaches its roots back into some previous decade and sends its seeds into some future period. It seems, however, worthmile even at the risk of overlapping to outline the events of this fourth decade.

\section{DXPATDING LINSOF}

This was a decade of expansion along many lines. The period 1918 - 1928 was characterized by the largest giving of any other ten years up to this time. This is partly due to the 75 Milion Campaign launched by Southern Baptists in which women played an important part.

During this decade five foreign Unions were organized; the Southern foman's Nissionary Union moved its headquarters to larger and more adequate quarters: the first of missionary program magazines for young people came into being; the southwide camp was begun: the Iiterature Department was heared by a paid secrutary; the nurses"Y.W.A. was named and put on a firm foundation; the kargaret Fund Department was headed 
by a Southwide Chairman and each state chose a state Chairman. To climax the decade the Ruby Anniversary was celebrated with enlarged plans and greatly expanding endeavor.

DEVELOPING FORIIGN NATIONAL WORK

BRAZILIAN At the opening of this decade we record . . A. the organization of the Brazilian Young Woman's Auxiliary. This fact in itself indicates expansion. The young women in the United States had walted nineteen years after the women were organized for their distinct organization while Brazil had waited only ten years.

It had been easy in some respects to work with the younger women in Brazil. Miss Minnie Landrum who had been sent to Brazil as Woman's Missionary Union worker gave attention to developing work among the young women so that their organization was perfected in 1919. 1 NIGEYIAN Few workers had gone to Nigeria, Africa but W.M.U. the work among the women had grown sufficiently for the Nigerian Woman's Missionary Union to be organized in 1919.2

1. Wite, Blanche, Op. Cit., p. 57

2. Report of Foreign Mission Board, 1920, p. 33 
JAPAN During this year the first student from a U. II.U. Southern Baptist mission field was admitted to the Woman's Missionary Union Training School. 1920 also witnessed the coming together of the Japanese women. The women were called to come to Fukuoka to consider an organization. The leaders had anticipated trirty women in attendance. Forty-four responded. The Japanese mission paid all expenses incurred in that meeting. The women sat about on the floor, their feet folded under them in true Japanese st le. Tea was served and the business of organizing the Japanese Moman's Missionary Union was conducted. 1

HUNGARIAN On April 12, 1923 in Budapest under the W.M.U. leadership of Mrs. Andras Udvarnoki the Hungarian Woman's Jíssionary Union was organized. In the early days of the twentieth century Mrs. Udvarnoki found that most of her time was consumed by visits from women who wished to talk with her about their problems. Realizing the need of the women this devoted woman went about organizing groups for the purpose of prayer and Christian fellowship. As these groups began to grow, an organization became necessary. It was perfected in 1923 and Mrs. Udvarnoki served as president until 1932.2

1. White, Blanche, Op. Cit., p.78

2. Ibid.:p.79 
CHIIEAN Another native Christian woman in another H. U. U. country was largely responsible for the fourth National Baptist Hission Union to have birth in this decade. Concepcion de Merino was one of the first Chilean women to catch a vision and to aid in bringing the women together for the organization of the Chilean Union on December 29, 1923.1

\section{CHANGES IN FIANS AND POLICIES}

HEADQUARTERS When the Convention met in Chat tanooga, MOVED

Tennessee, in 1921 there were important committees to report. Among them was a comittee which had been apointed in 1919. A progress report had been made in 1920 but a final report was presented for action in Chattanooga. The Comittee's special responsibility was to look into the question of moving the Union's headquarters. Two cities were suggested but the Annual Meeting voted in favor of Birmingham, Alabama. In August the move was made from Baltimore to a ten room office suite at 1111 Comer Building, Bimingham, Nlabama.

CHANGES IN PINNS In 1919 the Southern Baptist ConOF GIVING vention met in Atlanta. Up to this time each year at the Annual Meeting the amounts needed by the Home and Foreign Boards for their work of the coming year were apportioned among several states and the Wornan's 
Missionary Union in Annual session agreed each year to raise certain parts of the total amount. Added to this was the apportionments for orphanages, hospitals, ministerial relief, State Missions and other objects. In 1919 the women decided to ask the State Unions for certain amounts and to suggest that these amounts be divided on a percentage basis for all interests. This step paved the way for a Convention action which followed in 1924, the Cooperative Program. This change in plans for giving is also reflected in the increased gifts after 1919 . 1924 marks the beginning of what is known as the Cooperative Program. The term is used to designate a unified program of giving. Up to this time special offerings had been taken in churches at certain seasons for specific objects. It meant that throughout the jear many calls were made. This plan put all denominational causes into one budget on a percentage basis. This unified program was the culmination of the practice started by the women in 1919. At this time the women set up a budget providing for all phases of mission work on a percentage basis. They estimated the gifts of the current year from the gifts for the five preceeding years. The Cooperative Program established by the Southern Baptist Convention carried this plan on. All moneys went to a central office. An Executive Committee composed of members from each state and representatives from each 
interest such as Home Missions, Foreign Missions, Hospitals, etc. recommended the disbursement on a percentage basis. This Program is still in operation. 75 MILLION The men in their report on Woman's Work which CAM PAIGN was given to the Southern Baptist Convention commended the women for their gifts and sald "Included in this goodly total were numbers of gifts to the Heck Memorial, these being made in a large part by seven hundred Emergency women." I If one goes back to see who these women were one will discover that they were women who made gifts and signed pledges above their regular church gifts. These "Emergency women" were the inspiration for another movement which was started in the Convention. The growing work required increased funds. The work on all mission flelds now demanded bulldings and equipment to meet the expanding needs. The Nigerian Woman's Missionary Union had just been organized and needed help. Belleving that great oaks from little acorns grow Baptists launched what is known as the 75 Mililon Campalgn. "Pyramids are pyramids in vales", 2 said the poet. In giving, a gift may be big enough although it is only ten cents provided it comes from one who dwells in the vale of small

1. Minutes of Southern Baptist Convention, 1919, p. 29 2. Young, C., Nightly Thoughts 
possessions. This was the feeling of Southern Baptists as they set their faces to the task of raising the needed money. This task was to cover five years. The women took their share of the responsibility and soon had organizers in 838 of the 925 Associations and an organizer in 14,491 of the 24,851 churches.1

In 1920 when the Convention met in Washington the 75 Million Campaign was under way. Mrs. W. J. Neel of Georgia was the Chairman for the Woman's Division. The nine o'clock Prayer League which now has a definite connection with the regular Prayer Calendar was started for the success of the Campaign. Women responded with amazing interest. New emphas is was given to all phases of the work but a special effort to raise seventy-five mil lion dollars in five years was made. The women took the responsibility of raising one-fifth of this total amount. The great increase in gifts beginning in 1920 was, in part, a result of this unified effort and emphasis. MOTION In a former chapter2 reference was made to a CONS IDERED resolution which was presented to the Southern Baptist Convention for the admission of women delegates. In 1922 the Woman's Missionary Union sent another such communication to the Southern Baptist Convention. In response to this the following motion was passed:

1. Lackey, Margaret, Op. Cit., p. 5 
"The Convention is hereby advised that women are members of the Convention with all the rights and privileges of membership and that the Convention will instruct and does hereby instruct the Comittee on Comittees and Nominations to name both brethren and sisters according to their present qualifications, regardless of sex and that the word "brethren" wherever it occurs in the Constitution is hereby interpreted as referring to members of the Convention including brethren and sisters."I

This gave equal status to women.

CONSTITUTION The Annual Meeting in 1923 witnessed the changing of the Preamble of the Union's

Constitution. There were two important changes from the original.2 One change was in reference to the disbursement of funds. Heretofore, the Woman's Missionary Union collected funds which were disbursed entirely by the Boards of the Southern Baptist Convention but now a clause is added, "and by the Woman's Missionary Union Training School in Louisville, Kentucky," which reserves for the Union the right to participate in the disbursement of funds collected for their special school. The other change was to strike out the section "disclaim all intentions of independent action." It was made to read:

"We the women of the churches connected with the Southern Baptist Convention, desirous of stimulating a missionary spirit and the grace of giving among the women and young people of the churches and wishing to aid in the collecting of funds for missionary purposes to be disbursed by the Boards of the Southern Baptist Convention and by the Woman's Missionary Union Training School in Louisville, Kentucky, organize and adopt the following constitution."3

1. Mallory, Kathleen, Op. Cit., p. 25

2. See Above, p. 36

3. Mallory, Kathleen, Op. Cit., p. 6 


\section{NEW VENTURES AND EMPHASES}

STUDENTS Mrs. W. C. James who was chosen president in WORK

1916 had called attention to the needs of young people's work in her address, "The Road Ahead," which she delivered in 1919. Following this address a Student Activities Committee was appointed. The Secretary of the Woman's Nissionary Union was a member of that committee. The function of the Committee was to keep in touch with college students and to recommend to denominational agencies the points at which each respective agency could work best. This Committee, composed of representatives from the various agencies, functioned until it grew into the present Baptist Student Union, a distinct department now under the auspices of the Sunday School Board. ${ }^{1}$ the seeds for this thriving department were sown by the Woman's Missionary Union in 1920.

WHITE CROSS with the increased knowledge and interest in WORK the work of the Foreign Mission division it was quite natural that the year 1920 should witness the birth of the White Cross Department. The purpose of this Department was to stimulate interest in mission hospitals, to collect contributions of money and supplies. During the first year seven hospitals were helped. They were the

1. Report of Sunday School Board, 1937, p. 32 
institutions located at Ogbomoso, Africa and at Pingtu, Chengchow, Laichowfu, Yangchow, Wuchow and Hwangshien, China. Over 50,000 garments, towe Is, bandages, etc. and. \$9,687 were contributed. I Since 1920 this work has grown to include all the hospitals and dispenseries for foreign fields and denominational hospitals in the various states. Gifts amounting to $\$ 94,052.82$ were contributed during 1938.2 SERVICE For the first time in the history of the ACTIVITIES Southern Baptist Convention, work was begun in 1921 with the 500,000 Jews in southem territory. Women then, as now, were responsible for this move by the Home Missi on Board and for the salary of the worker. From year to year this salary has been provided for in the Home Mission offering which is a gift of Woman's Missionary Union. 3

The expanding work called for attention in the mountain section of the South. The State Woman's Missionary Unions had been instrumental in establishing and maintaining mountain mission schools. The Georgia Woman's Missionary Union supported in a large measure the Mary P. Willingham School. The Kentucky Union helped with Barbourville Institute, Hazard Institute and Magoffin Institute. The Missouri women gave support to Southwest Baptist College and North Carolina had helped with Mars Hill College from its beginning in 1837. South Carolina was giving support

1. Minutes of Annual Meeting, 1920, p. 19

2. Minutes of Annual Meeting, 1938, p. 58

3. Report of Home Mission Board, 1932, p. 11 
to North Greenville Academy. The dormitory is a memorial to South Carolina Baptist Woman's Missionary Union. Tennessee had Harrison-Chilhowie and Virginia had Buchanan and Blue Ridge. I

In 1926 an old building at 740 Esplanade, New Orleans, Louisiana, was secured and opened as a House of Refuge for the wayward. The Home Mission Board supervises the work but it is a special Home Mission service project for the Woman's Misionary Union.?

GRACE Florence Nightingale once said that nursing is an MCBRIDE Y.W.A. art; and if it is to be made an art it requires as hard a preparation as a painter's or sculptor's work for what is having to do with dead canvas or cold marble compared with having to do with the living body? The understanding of the obligation to young women entering upon this profession was being more and more recognized by the Woman's Missionary Union. Already some work was being done among the nurses in Baptist Hospitals but in 1923 the nurses' Department of Young Woman's Auxiliary was set up as a special Department. It was called the Grace McBride Department in tribute to Grace McBride who died in Siberia in a hospital at Omsk in the scourge of typhus fever. Miss McBride was the first foreign missionary nurse from the Woman's Missionary Union Training School. She was born in MansI. Whithoft, Mabel Swartz, Oak and Laurel, p. 46

2. Report of Home Mission Board, 1936, p. 14 
field, Ohio, December 11, 1885. After unusually excellent preparation for the work of a trained nurse she graduated from the Training School in Louisville, Kentucky, and was appointed to Hwangshien, China and sailed March, 1916. Her first two years were busy with language study but she also found time to minister to the sick and to the families of sick missioneries. Any suffering, any opportunity for service was a call to her. There was about her a sincerity and a love for the sincere which made her friendship attractive to the Chinese. She had a Iready demonstrated her ability to do good work not only as a nurse but to train others in the profession. When the call came from the United states forces in Siberia, her brothers were in the armies in France and she at once volunteered. When the Red Cross trains were being made up at Harbin she wrote her friends of the joy in preparation for this post of dire need. Then came the typhus fever plague. The Red Crossstarted supplies, doctors and nurses to go and clean up the plague-ridden towns. Obedient to the call Grace McBride went into the danger and fell in courageous conflict. 1 Y.W.A. One of the far-reaching events of 1923 was the camp CAMP at Ridgecrest, North Carolina, for young women. There were many Young Wonen's Auxiliaries in each of the states but there was no convention or congress

1. Grace McBride Y.W.A., Leaflet, p. 6 
which held its sessions at a time when young women in any number could attend, hence the members of Young Woman's Auxiliaries did not have a sense of unity. The purpose of the Camp was to stimulate mission interest and to give a sense of united effort and direction. The camp grew rapidly until 1938 when more than a thous and young women were registered. 1 From the Southwide camp similar camps have grown up in practically every state now affiliated with the Union. The Camp combines wholesome recreation, mission study, religious education and Christian living. Leaders' courses are found for work in the local churches.

NE' The crowning work of the decade called for LEADERS

$$
\text { additional workers. At the close of } 1922
$$

Miss Blanche White of Virginia was added to the staff as the first Woman' Misionary Union Field Secretary. Early in 1923 Miss Ethel Winfield was elected as Secretary of the Literature Department, the first person to hold this position. 2 In 1919 Miss Winfield had come to the work of the Woman's Missionary Union as assistant to the Secretary

1. Report of Young Peoples Secretary, 1938, p. 3

2. Minutes of Annual Meeting, 1926 p.9 
The first change of principals for the Woman's Missionary Union Training School came in 1925 when Mrs. Maude R. McLure retired.

\section{WONEN IEADING THE WAY}

PERSOIAL The Personal Service Department was showing SERVICE advances. A separate Director was chosen for this work. The title was later changed to Chalman of Personal service. With the coming of a Director a page in Royal Service was devoted to the growing activities. The name for settlements was changed to Good Will Centers as the unform name because the work was primarily a neighborhood work. A Handbook on Personal Service was written to give direction to the Department's work. In 1926 a new plant for the Good Will center in Louisville, Kentucky, was built. The growing work and improved social work methods made a new plant a necessity. ${ }^{1}$

MISSION A post-graduate course of Mission study had STUDY

been introduced at the 1919 annual meeting. Mission study worle had continued to show progress. In 1922 there were 8,982 classes held, 2,549 of which were among the young people. ${ }^{2}$ Certificates were provided for the full graded or canizations and a special Y. W. A. certificate and official seal was issued.

1. Mulilns, Mrs. E. Y., Op. Cit., p. 42

2. W. M. U. Year Book, 1922, p. I7 


\section{LITERATURE}

Back in 1911 Miss Heck had expressed the wish that someone would endow a missionary magazine for children. In 1922 World Comrades, a magazine for children, came into being. It was first issued as a quarterly, making Its first appearance September, 1922. By January the subscriptions had reached 6,000. By 1924 the magazine was changed from a quarterly to a monthly publication. Parallel with this publication was a Program quarterly for the Brazilian Woman's Missionary Union.

1922 also marks the publishing of the first Union Year Book. This has been a Jearly practice since that date. The Year Book carried the Plan of Work, which serves as the guiding principles for the Union.

One of the far-reaching efforts of 1928 was the development of a distinct literature for the Weeks of Prayer for Foreign and Home Missions. Each Jear since, small books have been published. They present the work of Home and Foreign Borrds. They are source books and serve to stimulate keener interest in the work.

The Missionary Library Fund which was also started in 1922 is closely connected with literature. Each year a special fund is set a side for the use of supplying each Southern Baptist woman missionary with needed 
literature in addition to the Union's Magazines. RUBY
ANNI IERS ARY Time strengthened and stabilized the organization of the Union and broadened the scope of its work. The decade closes with one of the outstanding occasions in the history of the Union. It was the Ruby Anniversary Celebration. Mrs. Carter Wright of Alabama was chairman. Realizing that there were great numbers of women and young people in Baptist churches who were not affiliated with the Nissionary organization of their church, Mrs. Wright led the Woman's Missionary Union to set high goals and to endeavor to reach out into communities where the organization was not at work. In many instances rural communities fell into this category. She set the following goals for the Union during the celebration: 40,000 new members, forty per cent increase in organizations, forty per cent increase in young people's organizations and $\$ 4,000,000$ as a financial goal. Over $\$ 3,500,000$ was given during the year, the largest gift of any year up to date. The organization was so well set up that each state knew just where its own weak points needed strengthening and the workers were so distributed that each section could be reached. Thirteen states reached their goals of forty 
per cent increase. This brought a tremendous number of new organizations as well as new individual members into the activitieg. ${ }^{1}$ However, there was a falling off within the next few years as the annual reports will show ${ }^{2}$ which would seem to indicate that high pressure had been used in some instances. A flaming torch became the emblem for the Anniversary. Three Annual Meetings featured certain phases of the celebration. The plans were launched in 1927. A progress report was made in 1928 and a final report presenting the progress and achiovements was featured in a pageant in Memphis, Tennessee, In 1929. The Intercessory League for Shut-Ins was an outgrowth of the preparation for the Anniversary. The election of an Associate Young Feople secretary was another outgrowth. A further achievement was a new emphasis on tithing. This led to new stewardship covenant cards, to the Tithing Story Contest and the Stewardship Declamation Contest sponsored for joung people. This was followed by a Stewardship Department which took up active work. Each

1. Report of Annual Neeting, 1928, p. 21

2. Report of Annual Keeting, 1929 - 1930 - 1931 
Department of work had been strengthened, larger gifts were avaliable for expansion, more women had been made conscious of the comprehenstve missionary program. The machinery which had been set up had worked efficiently and from these women were recruited new workers.

The Ruby Anniversary passed but its accomplishments in enlistment and gifts remain the acme of Union accomplishments. 1

The gifts of the decade will indicate the increase during the Anniversary. It will be noted that certain objects were added to the list. The reason for this (Ministerial Relief, christian Education and State Objects) has been mentioned before. 2 The rapid increase from $\$ 617,021.38$ to $\$ 2,403,875.96$ in one Jear was partially due to the record of gifts to added objects. Contributions had been made to these objects previous Iy but they had not been approved as Woman's Missionary Union objectives prior to 1920, The very concentrated effort put forth during the ri5 Million Campaign brought results in greatly increased gifts also. This Campaign came at a time when the country thought not in terms of depression. A large increase is recorded during the first year of the Campaign and a substantial level is

1. Cox, Ethleen B., op. Cit., p. 92

2. See above, p. 83 
held for the period from 1920 to 1925. There is a silght decrease in 1926 whi ch may be accounted for by relaxed efforts during the first year following the close of the Campaign. However, the next year saw a good increase $(\$ 838,333.13)$. There was no decrease until the depression.

CONTRIBUTIONS FOR THE DECADE 1919 - 1928

Year

1919

1920

1921

1922

1923

1924

1925

1926

1927

1928

Year

1919

1920

1921

1922

1923

1924

1925

1926

1927

1928

Year

1919

1920

1921

1922

1923

1924

1925
Foreign

$$
\begin{array}{r}
\$ 310,317.87 \\
636,178.09 \\
832,649.96 \\
668,062.88 \\
638,362.31 \\
707,552.79 \\
720,055.43 \\
602,723.85 \\
774,231.23 \\
643,645.58
\end{array}
$$

Christian

Education

$\$ 490,390.46$

$786,861.96$

$634,783.36$

$629,554.94$

$722,007.12$

$542,794.71$

$479,238.44$

$496,718.72$

$437,464.69$

Margaret

Fund

$\$ 2,771.65$

$3,458.71$

$6,606.10$

$8,304.67$

$6,600.00$

$7,200.00$

$15,873.62$

Home

$\$ 264,516.46$
$386,870.04$
$501,895.05$
$452,751.55$
$410,178.22$
$403,302.92$
$359,024.83$
$140,999.66$
$281,031.18$
$276,091.31$

State

objects

$\$ 777,894.92$

$1,061,402.70$

$1,246,983.30$

$923,810.06$

1, 043,937.88

$1,206,915.58$

$749,911.49$

$1,129,800.50$

$1,278,190.62$
Minis terial Relief

$56,449.22$

$107,856.26$

$93,118.04$

$96,572.94$

$89,709.96$

$68,466.93$

$52,131.24$

$72,148.96$

$73,970.15$

Bible

Fund.

$\$ 1,852.47$

$1,786.77$

$1,643.71$

$1,623.55$

$1,335.00$

$1,485.00$

- 1,650.00

$1,100.00$

$1,650.00$

$1,650.00$
Training

School

$\$ 37,562.93$

$50,847.75$

$70,480.87$

$57,988.49$

$63,870.40$

$55,969.46$

$58,084.15$
Tota.1

\$ $617,021.38$

$2,403,875.96$

$3,369,396.61$

$3,163,615.84$

$2,770,283.87$

$3,031,165.13$

2, $972,865.25$ 
Margaret

Fund

Year

1926

1927

1928

$$
\begin{array}{r}
9,705.06 \\
19,988.83 \\
23,790.94
\end{array}
$$

Training

School

$\$ 31,402.37$

$29,975.82$

$37,417.60$
Total

$\$ 2,067,212.11$ $2,805,545.24$ $2,772,220.891$

In the midst of the Ruby Anniversary Celebration the third Baptist World Alliance was held in Toronto, Canada, Mrs. W. J. Cox, president of the Woman's Missionary Union at this time, was the representative. For the third time the president of the Union was chosen as the presiding officer for the Woman's Division of the World Alliance for Baptists. Coming at this time it was easier for the women of the world to become acquainted with the work and plan of the Woman's Missionary Union.

It was also during the anniversary that Arizona entered the Union as the last state, thus the complete and full Southern Baptist territory now had official status with the Woman's Missionary Union.

No other one decade had witnessed such expansion as this decade. Five foreign Unions were organized, the Roumanian Union being the last one in this period. This organization brought together four language groups, Roumanian, Hungarian, Russian and German. The meeting for the organization was held in the Hungarian church. The president elect was a German woman and the Secretary was a Roumanian. Perhaps the greatest help in the Roumanian

\section{Minutes of Annual Meeting, 1939, pp. 64-65}


Union is the James Memorial Training School which was built and is entirely supported by the women of the South. It is located in Bucharest and trains young women for the work in all parts of Roumania.

$$
\text { As the decade closed Mrs. James Pollard, a former }
$$

Recording Secretary, admonished the women:

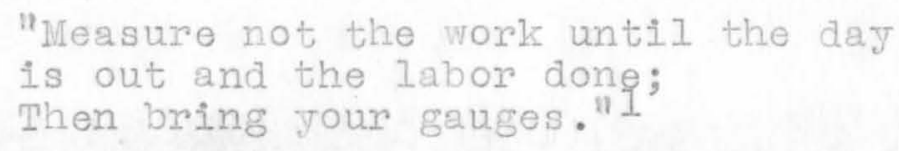

The fortieth year does not mark a finished task but these days of achievement were only the doors to the great fifth decade.

1. Wharton, Mrs. H. M., Fruits of the Years, p.94 
VI

A DECADE OF ANNIVERSARIES AND PROGRESS

$1928-\quad 1938$ 
A DECADE OF ANN IVERSARIES AND GRONTH (1928 - 1938)

I CONTINUED GROWTH

a- Royal Ambassador and Girls' Auxiliary Expansion

b- The Third Magazine Launched

c- Departments Established

d- James Memorial Training School

e- River Plate Woman's Missionary Union

- New Training $S$ chool courses and World Day of Prayer

g- Mountain Work

h- Italian Wornan's Missionary Union

\section{THE DECADE OF ANNIVERSARIES}

a - Training School Anniversary

b- Young Woman's Auxiliary Anniversary

c- Royal Ambassador Anniversary

d- Shuck Centennial

e- Sunbeam Band Golden Anniversary

f- Literature Department Jubilee

g- Golden Jubilee

III SUMMARY

a- Ten National Unions

b- Foreign Training Schools

c- observations

IV YEAR BY YEAR

a- 1929 The Window Started Rojal Ambassador Growth Girls' Auxiliary Expansion

b- 1930 Departments Established River Plate W.M.U.

c- 1931 Day of Prayer Around the World

d- 1932 Training School and I.W.A. Anniversaries and Personal Service Guide and. Mission Study Manual Written

e- Italian W.M.U. 1933 W.M.U. Work in all fields included in offering

f- 1934 Baptist World Alliance

g- 1935 Focus Weeks

h- 1936 Sunbeam Band Golden Anniversary Shuck Centennial

1- 1937 Purchase of New Site for the Training School Margaret Fund Enlarged Hungarian Training School Opened Japanese Training School Established

j- 1938 Golden Jubilee Celebrated 
A DECADE OF ANNIVERSARIES AND MARKED GROWTH 1928 - 1938

The decade of 1928 - 1938 saw the climax of the organization and activities of the Woman's Missionary Union. During the Ruby Anniversary celebration of 1928, the workers naturally reviewed the achlevements of the past forty years with some satisfaction, but there was little inclination to rest on the oars. Needs of various parts of the organization continued to demand development and expansion. The greatest total of contributions in the history of the organization was reached in $1929(\$ 3,500,166.59)$. This was presumably due to the activities of the Ruby Anniversary in the preceding year. The figures for 1930 and 1931 may be regarded as a return to normalcy, but continued decline $(1932$ - 1934) brought the totals to figures lower than any previous year since the World War (1919). This decline was no doubt due to the general economic depression, and the gradual increase after 1934 was similarly parrallel with improving business conditions. The funds suffering most from the decline in contributions were those for Home Missions, Ministerial Relief, Christian Education, and the Bible Fund, the last being entirely dropped after 
Page 101

1931. Fore1gn missions, the Margaret Fund and the Training School, although suffering declines, have maintained relatively high levels. On the other hand, State Objects (including state missions, Orphanages, state evangelists, denominational colleges and hospitals within the states), after a sharp decline have now reached a higher level than ever before (w1th the exception of the extraordinary years 1922 and 1929). This fund, when 1t began in 1920, was not quite one-third (32\%) of the total contributions, but in 1938 it was nearly one-half $(48 \%)$. Th1s may be accounted for by the fact that prior to 1920 each of the causes now Iisted under state Objects secured funds by making separate appeals to the churches and contributions had been made directly to many of these causes, but they were not objects Included in the financial goals of Woman's Missionary Union. After 1820 there was an effort to gatrer these gifts to isolated causes into the one combined fund under the title of State Objects. As information of the plan reached a greater number of the constituency, the response was better. It does not necessarily indicate that the contributions increased greatly, but may indicate rather, a difference in the method of reporting gifts to several objects under one head. 
Another factor that must be taken into account under the sums for State Objects is the emphasis placed on State denominational hospitals. This item increased the gifts in certain states. Another item which brought an increase in State objects gifts was the intensive summer work in the mountains and other undeveloped sections of some of the states. A program of teacher, training, Daily Vacation Bible Schools, and leadership courses was conducted largely by students from the Woman's Missionary Union Training School under the supervision of the State Woman's Missionary Unions. The expenses were not large, but called for an added contribution. The fact that State Objects has come to include all necessary phases of State Mission work would mean that gifts were not being dissipated but were concentrated in one channel which takes on greater proportions.

\section{CONTINUED GROWTH}

In 1929 was celebrated the Ruby Anniversary (fortieth year) of the Woman's Missionary Union. The celebration marks a period of great and substantial expansion. The year brought some lasting contributions. 
ROYAL AMBASSADOR The work among the boys was growing EXPANSION

and the demand for separate organizations and literature for Intermediates and Junior was insistent. Therefore, separate manuals were produced. Also the Royal Ambassador Guide for Counselors was published. Two additional. ranks were added to the Ranking System and two additional degrees were conferred on Intermediates. GIRL'S AUXIIIARY The Girl's Auxiliary was showing rapid ADVAITCE

growth. Advanced work was planned and circulated for the Intermediate Girl's Auxiliary members. Mission study courses were separated for Intermediates and Juniors, the G. A. ring was brought out and two Advanced Steps in the Forward Steps for members were added. MAGAZINES The Ioung Woman's Auxiliary had likewise grown in all three departments, church, college and hospital so that in september, 1929, a magazine, "The Window of Y.W.A." made its appearance. It is a monthly magazine and is the official organ of the Young Woman's Auxiliary. During this jear "The Why and How of W.M.U." was also published. DEPARMNETTS The stew ESTABIISHED Department and a Chaiman was named in 
January 1929. By 1930 there were two other divisions of the work which became distinct departments with Chaimen, namely the Personal Service and Mission Study Department.

JANES NEMOR IAL TRA INING SCHOOL
Another horizon beckoned Southern women and in 1929 Miss Earl Hester was sent to

Bucharest, Roumania, to become principal of the James Memorial Training school and to lead the women in their work. This school was started in 1925 after the resignation of Mrs. W. C. James as the Union's president in honor of her service. It was completed and opened in 1929.

At this same time Miss Lila Watson went to Shanghai, China to take over the task of preparing and translating programs for the Chinese Woman's Missionary Societies. This was a marked advance in the China Union which was made possible by gifts of the women of the south. By 1929 the Iiterature Department recorded marked growth. Over one million leaflets had been published by Woman's Missionary Union and about $\$ 36,000$ had been invested in mission literature.

RIVER PLATE The organization of the River Plate Woman's W.M.U. Missionary Union constitutes an epoch making event. Spanish, British, Italian, German, Indian and 
Russian blood flows in the stream of humanity from which the women of Argentina, Uruguay and Paraguay have come. Bound together by the River Plate, by a common language and a common need the women of these three Republics have united their efforts in what is today the River Plate Union.

Parallel with this happening in South America another significant event occurred across the world in Nigeria. The Woman's Missionary Union Nigerian Convention met in Benin City. It was composed of people speaking four or five different languages. The messages were given in English and interpreted in Yoruba. Eleven hundred people were present.

NEW TRAINING SCHOOL COURSES
No department has figured in a more important way in the work of the Union than the Woman's Missionary Union Training School in Louisville. In 1931 a change of principals was made. With the coming of the new principal, Miss Carrie Littlejohn, new courses were introduced which combined the scholarly with the practical. The degree of Naster of Religious Education was added after a three years' course. WORID DAY The year 1931 stands out in missionary history OF PRAYER also because of a feature which was introduced In connection with the Lottie Moon Season of Prayer. A 
Day of Prayer around the world was planned. For the first time Baptist women from all nations where there were Woman's Missionary Unions united in an effort for world missions. Friday was chosen as the day of prayer. Because of the difference in time in the various parts of the world, it meant that women were in reality at prayer somewhere in the world for the entire twenty-four hours of the day. MOUNTAIN From the days of great emphasis upon the Mountain SCHOOIS Mission Work, missionary societies have been interested in the mountain folk. The founding of the summer school for mountain preachers, a joint project of the Woman's Missionary Union and the Kentucks Baptists, was another indication of this interest. The school is located near Clear Creek Springs, Kentucky, and draws students from Kentucky, Tennessee and Virginia. From July, 1933, when the school had Its birth, up to 1937, the Woman's Missionary Union of Kentucky gave annually $\$ 500$. In 1937 the Southern Woman's Missionary Onion put an 1 tem of $\$ 1,000$ in the Home Mission offering for this school. ITALIAN In 1932 a sum was included in the Christmas W.M.U. Offering for Woman's Missionary Union work on each forelgn fleld where Southern Baptists had worked. In 1933 with the money from this fund representative women 
were brought to Rome from societies and the Woman's Missionary Union of Italy was organized. ${ }^{1}$ The organization really goes back to 1914, when, in Rome, "Ladies Jociety" was organized. One of the first things this new society did was to vote to send to the Woman's Missionary Union of the South a little contribution because they wanted to share in the Juds on Centennial.

\section{A DECADE OF ANNIVERSARIES}

Highways that wind over and around the mountains hold particular interest for thise who follow the road. Along many of these roads wide spaces have been built beside the road at 1ts crest to make observation posts for travelers. Anniversaries, like such vantage points, persuade one to pause for observation.

TRAINING SCHOOL 1932 brought the significant twenty-fifth ANNIVERSARY

Anniversary of the Woman's Miss Ionary

Union Training school and the Young Woman's Auxil1ary. In speaking of the Training School at the Anniversary time, Mrs. Mullins sald, "It is eternal in 1 ts motives and purposes, the Kingdom of God being 1ts objective, Christ the gulding star of 1ts activities. It has a place in immortal his tory."2

YOUNG \#OMEN'S AUXILIARY ANNIVERSARY
The Young Women's Auxiliary entered its celebration by inaugurating a

1. White, Blanche, op. Cit., p. 91

2. Mullins, Mrs. E. Y., Op. C1t., p. 72 
nation-vide broadcast. During this anniversary, the Y.W.A. Camp at Ridgecrest, North Carolina, had the Iargest attendance in its existence. During the Anniversary year the Y.W.A. monogram seals and Anniversary Booklet were published. Two other publications were circulated during this Anniversary year: namely, The Personal Service Guide and the Mission Study Manual.

ROYAL Royal Ambassadors observed their twentyANBASSADORS fifth Anniversary in 1933. During the year new impetus was given to Conclaves and Summer Camps. SHUCK 1936 brought three additional observation GENTEININAL points. The first was the Shuck Centennial, commemorating one hundred years of Baptist life in China and paying tribute to J. Lewis Shuck and Henrietta Hall Shuck, the first Baptist missionaries from America. This celebration was a stimulus to greater missionary endeavor. A gift of $\$ 100,000$ as a Shuck Memorial was given by the Woman's Missionary Union, this gift to be distributed to the special Training Schools on foreign fields. Since Mrs. Shuck was responsible for starting the first mission schools it seemed a fitting thing that the gift should be made for the schools. Mrs. F. Y. O. Iing the present Secretary for the China Woman's Missionary Union was brought to the States as 
Page 109

a guest of the Woman's Missionary Union, S.B.C. as guest speaker at the Convention in St. Louis in 1936. Mrs. Iing said, "One hundred years is but a short time in the world! What a change has been made in China since the dawn of Christianity." As a result of the centennial of Baptist mission work in China the All-China Woman's Missionary Union was perfected.

SUNBEAM BAND ANNIVERSARY
The second Anniversary to arouse wide interest was the Fiftieth Anniversary of Sunbeam Bands

which had been started and fostered by Dr. George Braxton Taylor of Hollins, Virginia. Observers had seen the movement grow to have 6,386 organizations with 103,232 members. Sunbeams had given in the one year \$28,410.94 to missions. Observing the potentialities in the Sunbeam Bands one is led. to realize that the future missionary history of southern Baptists is largely contingent upon Sunbeam Band members. ITTERATRE DEPARTMENT The third Anniversary was the ANNIVERSARY Jubilee of our mission literature.

"The pen is mightier than the sword" runs the proverb. Southern women realized their indebtedness to Maryland Baptists for the initial gift in 1906 of around $\$ 1400$ with which the Iiterature Department was inaugurated. In the

1. Minutes of Annual Meeting, 1936, p. 132 
Literature Jubilee year 1,045,130 free leaflets were distributed by the Department. Special help was given by the Department to the Jews in printing "Friends of Israel" and to the Negro women in a gift of $\$ 250$ to inaugurate a Iiterature Department in their Auxiliary.

It was not unusual that a year of such celebrations should witness many advances, among them the moving of the Brazilian Woman's Missionary Union headquarters to the new Publishing House Building where sufficient space and equipment had been provided by the Woman's Missionary Union, S.B.C. GOLDEN Several important steps were taken in 1937. PIans JUBILEE

for the Golden Jubilee were made with the goals of ten percent increase in organizations, ten percent net increase in gifts, $\$ 60,000$ as a gift to the Woman's Missionary Union Training School for the purchase of a new site for the growing school. Late in 1937 this purchase was effected. Sunbeam Babies, the Cradle Roll of Woman's Missionary Union, was set up for the first time during the Golden Jubilee. The women in Annual session voted to include the sons and daughters of Home missionaries in the Margaret Fund.1 The Golden Anniversary Annual Meeting was held in Richmond, Virginia, the city of the birth of the organization. The year which marked the fifieth Anniversary of the Union

1. Minutes of Annual Meeting, 1937, p. 70 
in the United States also marked the thirtieth Anniversary of the Brazilian Woman's Missionary Union. Waldomira Almeida came to Richmond as the official messenger from Latin Amer1ce.

Victories and achievements were recorded in the sienificant Anniversary year. The record shows a total eift to Home Missions of $\$ 7,818,129.83$ since 1888 . The total gift to Foreign Missions was $15,577,904.20 .^{1}$

It is a long cry from the beginning of this speial offering in 1895 when it was known as "Self-Denial Offering". Later the name was changed to "Thank Offering" and in 1934 it was again changed to the "Annie Armstrong OfferIng for Home Missions", in honor of Miss Armstrong, the first secretary. 2

The Lottie Moon Christmas offering had grown from the first offering of $\$ 3,000$ to the last year's offering of $\$ 300,000$. One recalls that the first $\$ 3,000$ offering was In response to a letter from Miss Lottie Moon in China requesting two relpers. This came in 1888, three months after Woman's Missionary Union was organized. Miss Armstrong wrote letters by hand to 1500 societies. The response to those letters brought the gift of 3,000 .

1. Report of Annual Meeting, 1938, p. 64

2. Wharton, Mrs. H. M., Fruits of the Years, p. 61 
The report of the Golden Jubilee year also showed 34,594 Woman's Missionary Union organizations. Virginia, Texas and North Carolina each had over 3,000; Georgia, Tennessee, South Carolina, Alabama, Kentucky and Missouri each had over 2,000 organizations out of the total of 34,594 .

The growth of the Woman's Missionary Union can be read in the constitutional changes necessary to care for the increasing state representation at Annual Meetings. In 1888 each state could have three delegates; 1890, it was four; 1901, eight; 1908, twenty; 1915, twenty-five; 1919, forty, and in 1930, forty-five. For the Golden Jubilee Celebration the number was increased to fifty.

\section{SUMMARY}

NATIONAL W.M.U. Besides the growth in the United States ORGANIZATIONS

$$
\text { there have been ten National Woman's }
$$

Missionary Unions which have developed as an outgrowth of this missionary movement. They are as follows:

$\begin{array}{lccc}\text { Country } & \begin{array}{c}\text { Date of } \\ \text { organization }\end{array} & \begin{array}{c}\text { No. of } \\ \text { organizations }\end{array} & \begin{array}{c}\text { No. of } \\ \text { members }\end{array} \\ \text { Brazil } & 1908 & 366 & 8067 \\ \text { China } & 1910 & 150 & 4579 \\ \text { Argentina } & 1913 & 50 & 1570 \\ \text { Mexico } & 1918 & 33 & 551 \\ \text { Nigeria } & 1919 & 174 & 4728 \\ \text { Japan } & 1920 & 17 & 217 \\ \text { Hungary } & 1923 & 23 & 523 \\ \text { Chile } & 1923 & 42 & 749 \\ \text { Roumania } & 1928 & 350 & 7000 \\ \text { Italy } & 1933 & 41 & 509\end{array}$

1. Report of Annual Meeting, 1938 
In Spain, Jugo-Slavia, Palestine and Syria there are societies but they have not yet been drawn together into a National Union.1

FOREIGN TRAINING A further indication of growth is the SGHOOIS

Foreign Woman's Missionary Union

Training Schools. In the spring of 1937 Miss Ruth Mahan was sent to Budapest, Hungary, to take charge of the nev Woman's Missionary Union Training School. She was to be supported by the women of the south.

The Training School in Japan was opened during the same year. Thus, 1937 witnessed the birth of two new Foreign Training Schools. At present there are schools in several countries as follows:

$\begin{array}{ll}\text { Argentina } & 2 \\ \text { Brazil } & 2 \\ \text { China } & 4 \\ \text { Japan } & 1 \\ \text { Hungary } & 1 \\ \text { Roumania } & 1\end{array}$

\section{OBSERVATIONS}

The history of Baptist women in their organized capacity parallels that of early New Testament Christianity. The beginning was small and insignificant. Difficulties appeared on every hand. Precedents must be broken. Questions must be answered. The organization as it is seen in this fifth decade did not spring into full grown

1. Foreign Mission Board Report, 1938, p. 49 
existence. The Woman's Missionary Union organization grew until it embraced the entire Southern Baptist Convention territory and shared in the fostering of all its activities. Dr. J. B. Thom said, "By common consent today the Wornan's IIissionary Union is one of the most complete and efficient religiodis movements in the world." I Throughout the pages of this thesis we have observed a steady growth in missionary interest and concern. The purpose of "stimulating the missionary spirit" has been Vitalized to such an extent that missionary enthusiasm has spread from a small group of women to practically all southern Baptist churches. The Woman's Missionary Union has been instrumental in initiating such activities as the movement among Baptist students, the Daily Vacation Bible School among the Baptist churches, Camps and conclaves for Baptist Joung people, the cooperative program for Southern Baptists, prescribed courses of mission study with appropriate awards, a system of merits for Junior and Intermediate boys and girls in missionary education, a full graded system of missionary education for the individual churches, the Church Building Loan Fund, Fund for the education of the children of missionaries, the school for training young

1. Minutes of Southern Baptist Convention, 1936, p. 20 
women for mission work and other types of religious service. This phase of the work has spread to six foreign countries. Another part of the purpose, "the collecting of funds for missionary purposes" has been carried forward as the increase in mission funds will show. The total gifts recorded in 1889 amounted to $\$ 30,773.69$. In fifty jears the gifts had increased to a total of $\$ 2,357,003.42$ in 1938 . The list of objects to which the Woman's Missionary Union contributed had also grown from two (Foreign Missions and Home Missions) to seven, one of which included all objects supported by the state Mission Boards (Foreign Missions, Home Missions, Ministerial Relief, Christian Education, State Objects, Margaret Fund and Training School.)

The purpose of "disseminating missionary information" has been furthered through various avenues, none of which has been more effective than the missionary magazines. The first, Our Mission Fields, was launched in 1907 as a quarterly. Today, the Woman's Missionary Union publishes three magazines, Royal Service, World Comrades, and The Window of $Y$. W. A. with a combined subscription of more than 130,000. In addition to the magazines, missionary knowledge has been spread through mission study books, manuals of methods for each grade of work and a guide book 
for each year, State Conventions, Regional Conferences, Schools of Missions, Associational Meetings, and Federation Meetings, have all been used for spreading missionary knowledge.

The Staff for the Woman's Missionary Union has been increased from one unsalaried secretary to eight salaried officers, ten paid contributors to the missionary magazines, and twelve office workers. Iikewise, each state has a state office staffed by salaried executives and clerical help.

Since the year of 1889, when three missionaries were sent out by the first Christmas offering, the Woman's Missionary Union has supported many missionaries. In 1938 the Christmas offering was supporting one hundred twenty-five 4 or almost one third of all those supported by the Southern Baptist Convention. Another way of increased efficiency has been to share in training the vational Christians through Foreign Training Schools, of which there were six. In 1936, a gift of $\$ 100,000$ was given for this purpose. The ten National Woman's Missionary Unions which have been developed and literature in the languages of the various groups is another approach to a better informed and more efficient constituency. 
The Woman's Missionary Union has grown from a group to which the men were reluctant to give status to an organization whose representatives sit on all important committees and Boards of the Southern Baptist Convention. The Union shares in every policy-making group of the Convention and while the Union has preferred to remain an auxiliary body, it shares in responsibility and recognition equal to any Board of the convention. It is an autonomous group, but reports its actions to the Southern Baptist Convention, not for approval, but for information.

From an organization which started as a praying group the Woman's Missionary Union has advanced to a departmentalized organization with each department of activity headed by a chairman whose responsibility is to develop that phase of the work; namely Literature, White Cross Work, Young People's Work, Stewardship, Personal Service, and Mission Study. The last to be established were the Mission study and Personal Service, in 1930.

The moving finger of time has witten a half century of Woman's Missionary Union history. The years have come and gone, generation has followed generation. Scientists tell us how fast light travels but no one can tell with assurance the rapidity, the duration of the wave lengths of a movement 
such as the Woman's Missionary Union.

There is a legend which says that when Julius Caesar and his Roman generals were taking their armies to some foreign shore in a campaign of conquest they would sometimes burn their boats behind them after reaching the shore so that their soldiers would understand that they must either conquer or die. While the report for the years is good the Woman's Miss ionary Union has reached the shore after the voyage of a half century and the time has come to burn the boat of the past and enter upon new endeavors. New oceans Iie before the Union; new vessels are already being launched into the deep of a new day.

"We break new seas today Our eager keels quest unaccustomed waters, And from the vast uncharted waste in front, Our mystic circles leap

To greet new prows with mightiest possibilities; for now the Woman's Missionary Union faces the horizon of a. century. 
Contributions for the Decade 1928-1938

Year
1929
1930
1931
1932
1933
1934
1935
1936
1937
1938

Year

1929

1930

1931

1932

1933

1934

1935

1936

1937

1938

Year

1929

1930

1931

1932

1933

1934

1935

1936

1937

1938

$$
\text { Foreign }
$$

$\$ 776,958.77$

$658,238.10$

$611,572.47$

$549,695.18$

$468,935.11$

$473,190.93$

$515,895.71$

$550,393.83$

$590,087.02$

$578,628.10$

Christian

Education

$\$ 727,202.97$

$535,304.22$

$509,244.37$

$431,517.45$

$312,339.70$

$232,229.96$

$275,295.38$

$235,387 \cdot 12$

$284,010.72$

$322,168.55$

Margaret

Fund

\$ 24,403.44

$27,349.06$

$19,323.47$

$19,185.42$

$16,959.35$

$15,675.45$

$15,072.41$

$16,043.72$

$17,293.49$

$16,255.61$
Home

\$ 451,352.68

$248,118.08$

$270,849.35$

$260,325.69$

$234,813.30$

$183,126.63$

$186,635.27$

$199,752.84$

$227,647.56$

$249,135.97$

State

objects

$\$ 1,404,688.16$

$1,013,997.46$

1,037,201.77

856.556 .06

$770,624.53$

$645,020.09$

$863,898.82$

$908,728.71$

$981,518.96$

$1,119,891.43$

Training

School

$\$$

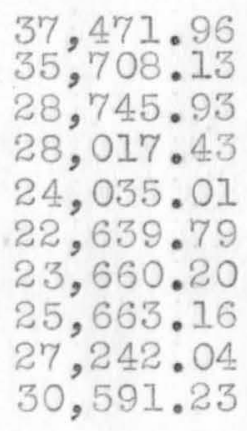

Minis terial

Relief

$\$ \quad 76,438.61$

$67,210.67$

$51,547.29$

$51,973.75$

$39,461.78$

$35,423.04$

$35,345.20$

$36,401.01$

$37,986.78$

$40,332.53$

Bible

Fund

$\$$

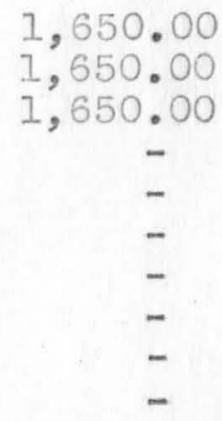

Total

$\$ 3,500,166.59$

$2,587,575.72$

2,530,134.65

$2,197,270.98$

$1,867,168.78$

$1,607,305.89$

$1,915,802.99$

$1,972,370.39$

$2,165,786.57$

$2,357,003.42$ 
Total Gifts for the First Fifty Years

\begin{tabular}{|c|c|c|}
\hline Foreign Mission & Home Mission & $\begin{array}{c}\text { Ministerial } \\
\text { Relief }\end{array}$ \\
\hline$\$ 15,577,904.20$ & $\$ 7,818,129.93$ & $\$ 1,234,239.38$ \\
\hline $\begin{array}{l}\text { Christian } \\
\text { Education }\end{array}$ & $\begin{array}{l}\text { State } \\
\text { objects }\end{array}$ & $\begin{array}{l}\text { Bible } \\
\text { Fund }\end{array}$ \\
\hline $9,438,930.82$ & $\$ 20,208,573.29$ & $42,120.10$ \\
\hline $\begin{array}{c}\text { Margaret } \\
\text { Fund }\end{array}$ & $\begin{array}{r}\text { Training } \\
\text { School }\end{array}$ & Total \\
\hline $342,334.12$ & $1,185,425.47$ & $\$ 55,847,657.3$ \\
\hline
\end{tabular}


VII

A P PE N D IX 


\section{A PARTIAI LIST OF EARLY MISSIONARY SOCIETIES}

Only the societies which carried the full title Female Missionary Societies are listed and not those marked "F.M." as Foreign Mission groups were often marked simply "F.M.", and that marking in the records does not give any clue as to whether they were Female Missionary Societies or just Foreign Mission groups.

NAME

Hyco Female Cent Society

Sewing Circle Richmond

Wadmalow \& Edisto

Female Mite Societies

Charleston Juvenile \& Educational Society

Richmond Female Baptist Missionary society
STATE DATE

N.C. $\quad 1810$

Va.

S.C.

1811

$*$
SOURCE

Minutes of N.C. Society for Foreign and Domestic Missions 1816, in pamphlet 1888 .

The First Century of first Baptist Church, Richmond.

linutes of Charleston Association, 1812

S.C. $\quad * \quad$ History of First Baptist Church of S.C.

Va. 1813 Second Annual Report of Baptist Board of Foreign Mis sions

Fredericksburg Female Society for Foreign Missions
Va. 1814 Same as above 


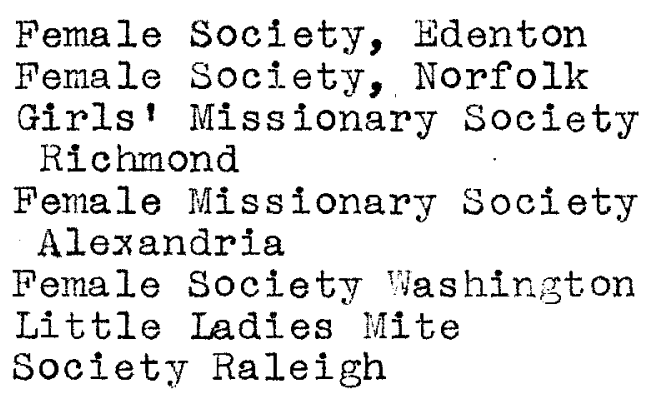

Welch Neck Female Auxiliary Society

S.C. $1819 \quad \begin{aligned} & \text { Minutes of } \\ & \text { Charleston } \\ & \text { Association, } \\ & 1820\end{aligned}$
Ky. $1822 \quad \begin{aligned} & \text { Old letter in } \\ & \text { newspaper }\end{aligned}$

N.C. $1817^{*}$ History of Sandy Creek

S.C. 1829 Minutes of Charleston Association

$\begin{array}{lll}\text { S.C. } & 1832 & \text { " } \\ \text { S.C. } & 1836 & \text { " } \\ \text { S.C. } & 1842 & \\ \text { S.C. } & & \\ & & \end{array}$

Miss. 184.1 Minutes of State Convention 
Female Missionary Society

Whird Baptist Church

Richmond

Female Domestic Missions

Soclety, 2nd Richmond

Female Foreign Missions society, 2nd $\mathrm{K}_{1}$ chnond

Female M1silonary society Rural Springs

Female Missionary Society First Baptist, Baltimore

- Misisionary society

Bethel

$\begin{array}{ll}n & n \\ n & n \\ n & n\end{array}$

$$
\begin{gathered}
\text { "Jonesboro } \\
" \text { Jalem } \\
\text { " Clairborne } \\
\text { Roupes } \\
\text { Valley }
\end{gathered}
$$

Flat Rock Female

Missionary Society

N. C

Ala

1822

1822

Ala.

Ala.

1822

1822

1836

1822

History of

Baptist of

Ala. by $B$.

F. Riley

it

it ennial Fegis ter, 1836

u

$\|$

"

Constitution

Raleigh Female Benevolent society

N.C. $\quad 1830$

Minutes of First Annual state Baptist Convention, 1831

Brandon Foreign Mission Society

Miss. 1832 Pamphlet by

Mrs . A. J. Qulnch, 1888 of the isociety preserved in Theoligical Seminary 


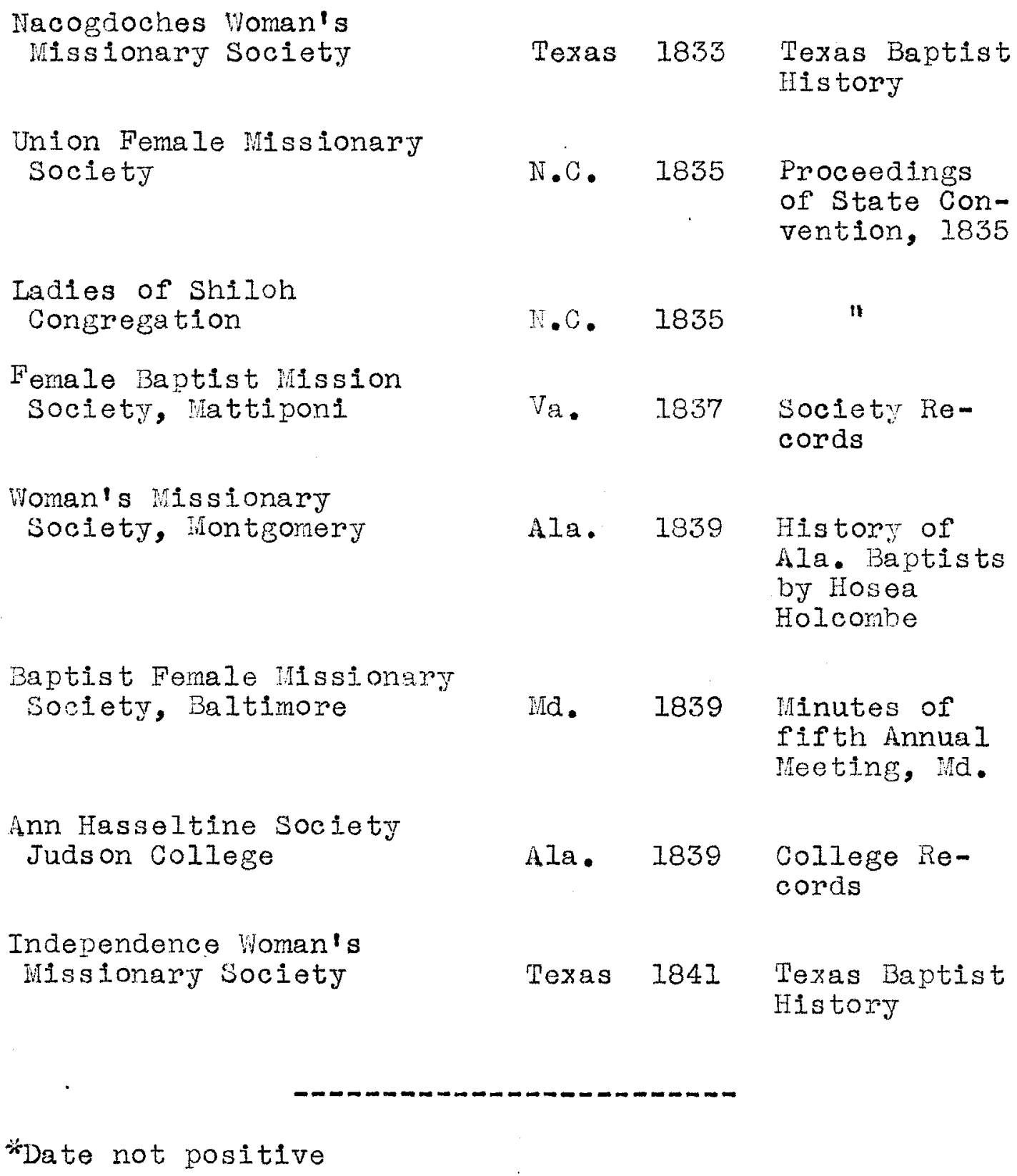




\section{B THE STATS CENTRAL COMPITTESS}

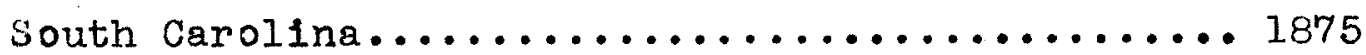

Virginia.............................. 1875

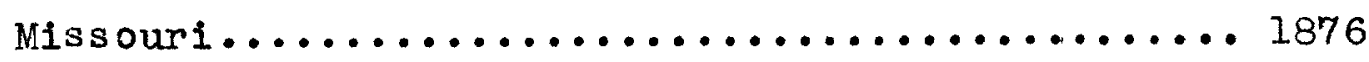

North Carolina.......................... 1877

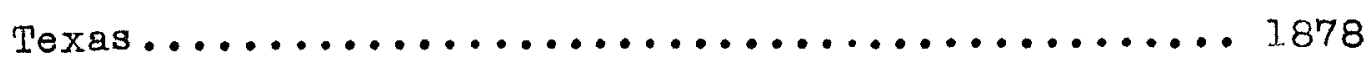

Georgia............................... 1879

Kentucky................................ 1879

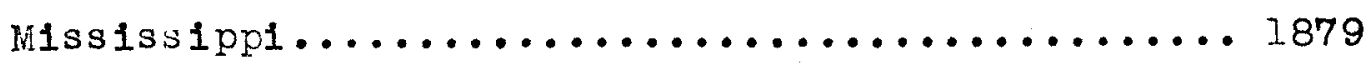

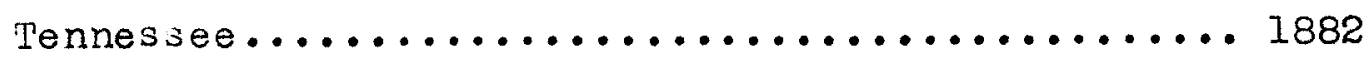

Arkansas .............................. 1883

Alabama............................... 1884

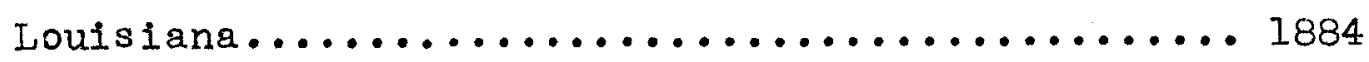

Florida.............................. 1894

States not listed were not in any way organized before the organination meeting in 1888 and only Florida went through the period of having a Central Committee after the organization. The other states which are now afflliated with the Woman's Missionary Union started their work under Executive Committees. 
C FIRST STATE VICE-PRESIDENTS OF THE UNION 1888

$\begin{array}{ll}\text { Arkansas } & \text { Mrs. M. D. Early } \\ \text { Florida } & \text { Mrs. B. B. Chiply } \\ \text { Georgia } & \text { Mrs. S. Wilson } \\ \text { Kentucky } & \text { Miss Eliza Broadus } \\ \text { Louisiana } & \text { Mrs. M. Alfred } \\ \text { Maryland } & \text { Mrs. A. A. Rowland } \\ \text { Missouri } & \text { Mrs. S. Y. Pitts } \\ \text { South Carolina } & \text { Mrs. M. A. Hewitt } \\ \text { Tennessee } & \text { Mrs. A. Nelson } \\ \text { Texas } & \text { Mrs. A. C. Ardrey }\end{array}$

In 1889

Virginia

Mrs. W. E. Hatcher

Mississippi

Mrs. A. W. Hillman

In 1890

Alabama

Mrs. George B. Eager

In 1891

North Carolina

Miss F. E. S. Heck

West Arkansas and Indian Territory

Mrs. May Moss

In 1895

District of Columbia Mrs. C. A. Stakely 
D PLACES OF NEETINGS, YEAR BY YEAR AND GIFTS

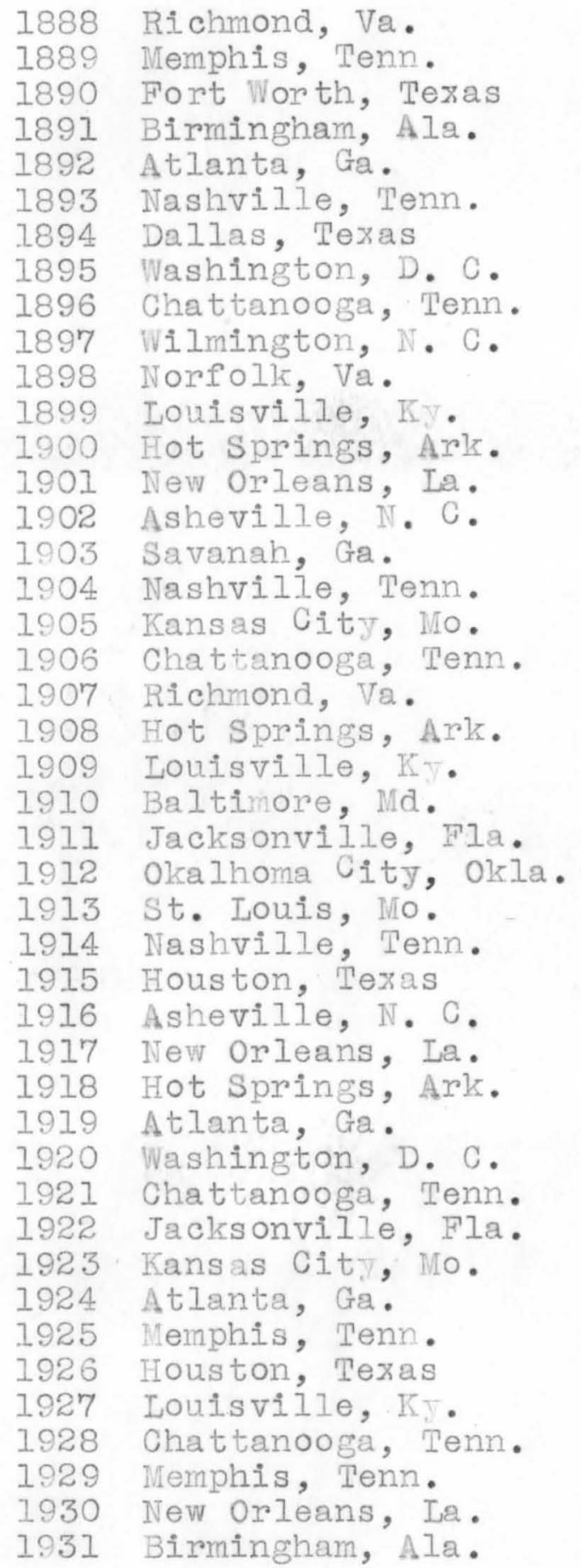

$$
\begin{array}{r}
30,773.69 \\
31,560.41 \\
38,990.34 \\
44,282.80 \\
62,336.75 \\
45,128.59 \\
48,449.25 \\
56,342.19 \\
34,317.38 \\
33,395.43 \\
38,562.69 \\
51,236.20 \\
52,973.27 \\
54,776.52 \\
56,403.80 \\
73,090.76 \\
95,294.32 \\
103,601.90 \\
125,124.04 \\
186,198.58 \\
172,764.07 \\
215,959.54 \\
226,507.91 \\
267,957.25 \\
290,728.72 \\
381,319.77 \\
363,018.78 \\
405,933.86 \\
467,471.34 \\
504,812.74 \\
617,021.38 \\
2,403,875.96 \\
3,369,396.61 \\
3,163,615.84 \\
2,770,283.87 \\
3,031,165.13 \\
2,972,865.25 \\
2,067,212.11 \\
2,805,545.24 \\
2,772,220.89 \\
3,500,166.59 \\
2,587,575.72 \\
2,530,134.65 \\
\end{array}
$$


1932 St. Petersburg, Fla. 1933 Washington, D. C.

1934 Fort Worth, Texas

1935 Memphis, Tenn.

1936 St. Louis, Mo.

1937 New Orleans, La.

1938 Richmond, Va.
$2,197,270.98$

$1,876,168.78$

$1,607,305.89$

$1,915,802.99$

$1,972,370.39$

$2,165,786.57$

$2,614,556.16$ 
E NATIONAI WOMAN'S MISSIONARY UNIONS

$\begin{array}{lr}\text { Argentina } & 1913 \\ \text { Brazil } & 1908 \\ \text { China } & 1910 \\ \text { Chile } & 1923 \\ \text { Hungary } & 1923 \\ \text { Italy } & 1933 \\ \text { Japan } & 1920 \\ \text { Mexico } & 1918 \\ \text { Nigeria } & 1919 \\ \text { Roumania } & 1928 \\ \text { River Plate } & 1930 \%\end{array}$

*This takes in Argentina, Uruguay, and Paraguay 


\section{F WATCHWORDS}

1888 Go Forward--Let us consider one another to provoke unto love and to good work. Heb. 10:24

\section{Same as above}

1890 For God and Home and Every Land

1891 - 1895 Same as above

1896 Love and Labor

1907 This year began the yearly watchword or motto Larger Things

1908 Higher Things

1909 The people that know their God shall be strong and do exploits. Dan. 11:32

1910 Whatsoever He saith unto you do it. John 2:5

1911 our suffering is from God. II Cor. 3:5

1912 Teaching them to observe all things whatsoever I command you. Matt. 28:20

1913 Serve Jehovah with gladness. Ps. 100:2

1914 Be strong in the Lord and in the strength of his might. Eph. 6:10

1915 Have faith in God. Mark 11:22

1916 Steadfastly in prayer and ministry. Acts 6:4

1917 Herein is my Father glorified that je bear much fruit--so shall ye be my disciples. John 15:8 
1918 Arise shine, for thy light is come. Isa. 60:1

1919 Serve the Lord with gladness. Ps. 100:2

1920 Let us consider one another. Heb. 10:24

1921 Ask and it sha $\perp 1$ be given you, seek and ye shall find, knock and it shall be opened unto you. Matt. $7: 7$

1922 God is abıe. II Cor. 9:8

1923 Same as above

1924 Behold I send you forth. Matt. 10: 16

1925 Ascribe unto Jehovah the glory due unto his name. Ps. 29:2

1926 Fina lly be strong in the Lord. Eph. 6:10

1927 Seek Je first the Kingdom of God. Natt. 6:33

1928 Thy Kingdom comẹ. Luke $11: 2$

1929 Follow me. Matt. 9:9

1930 I am the Way, the Truth and the Life. John 14:6

1931 For God so loved the world that He gave His only begotten Son that whosoever believeth on him should not perish but have everlasting life. John $3: 16$

1932 Jehovah Liveth. Ps. 18:46

1933 Go--tell--He goeth before you into GaLilee. Iiark. 16:7

1934 Render unto Caesar the things that are Caesar's and unto God the things that are God's. Luke 20:25

1935 In the name of God we will set up our banners. Ps. 20:5

1936 Lay not up for yourselves treasurers upon earth. Natt. $6: 19$ 
1937 Not by might nor by power but by my spirit saith the Iord of Host. Jech. 4:6

1938 Give unto the Lord the glory due unto his name; bring an offering and come into His courts. Ps. 96:8 


\section{BIBLI OGRA PHY}

BOOKS

Bucy, Wilma, The Why and How of W. M. U., Nashville, Tenn., Boarăman ress, 1928

Carver, W. 0., Missions, the Plan of the Ages, New

York City, ReveII Co., 1909

Carver, W.0., All the World in All the World, NashVilie, Tenn., Boardman Press, I918

Carver, W. 0., The Course of Christian Missions, New York City, Re vell Co., 1932

Cole, Arthur Charles, Irrepressible Conflict, New York C1ty, the MacMiIIan Co., 1934

Copass, Mrs. B. A., Fifty Golden Years in Texas,

Dallas, Texas, Baptist Standard, 1934

Cox, Ethleen B., Following in His Prain, Nashville, Tenn., Boardman Press, 1938

Fosdick, H.E., The Neaning of Prayer, New York City, Abingdon ress, 1915

Gordon, S. D., Quiet Talks on Prayer, New York City, Reve11, Co., 1904

Heck, F.E.S., In Royal Service, Richmond, Va. Rice Press, 1912

Knight, W.H., Missions in Principles and ractice, Nashville, Tenn., Boardman Press, 1929

Lawrence, J.B., The Bible a Missionary Book, Atlanta, Ga. Home Mission Board, I935

Lawrence, J.B., Taking Christ veriously, Atlanta, Ga., Home Mission Board, 1935

Lawrence, Una Roberts, Fersonal service Guide, Blrmingham, Ala., W.M.U. Literature Dept.', 1934

Lawrence, Una Roberts, The King's Own, Nashville, Tenn., Boardman ress, 1924 
Lawrence, Una Roberts, Lottie Moon, Nashville, Tenn., Boardran Press, 1925

Lawrence, Una Roberts, Home Mission Trails, AtIanta, Ga., Home Mission Board, 1931

Lackey, Margaret, H. M. U. Service, Nashville, Tenn•, Boardman Press, 1923

Lemouze, Arthur, Homeland Harvests, New York, Friendship Press, 1939

Mallory, Kathleen, Manual of H. M. U. Methods, Nashville, Tenn., Boardman Press, 1917

Matthews, Basil, The Clash of World Forces, New York City, Abingdon Press, 1927

McAfee, Cleland Boyd, Changing Forelgn Missions, New York City, Reveli Co., 1927

Mullins, Wrs. E. Y., House Beautiful, Nashville, Tenn., Boardman Press, 1932

Nasters, Lols, Gospel Trails, Louisville, Ky•, Western Recorder, 1929

Mather, Juliette, Leading in Missions, Nashville, Tenn., Boardman Press, 1924

Perry, Mrs. E. N., V. M. U. Pathes, Louisville, Ky • Western Recorder, 1936

Perry, Mrs. E. N., History of Kentucky H. M., Louisvilie, Ky., Western Recorder, 1935

Phillips, Ulrich B., Life and Labor in the old South, Boston, Mass., Little-Brown \& Co., 1929

Pye, Mrs. W. D., Through the Golden Yesrs in Arkansas, Little Rock, state Mision Board, 1936

Pye, Mrs. W. D., History of Arkansas M. M. U., Little Rock, Ark., State Misilon Board, 1937

Smith, Miles M., The Torch Bearer, Philadelphia, Pa., Juds on Press, 1934 
Stephenson, George M., American Ilistory to 1865, New York, Harper and Brothers, 1940

speer, Robert i., Church and Missions, Garden City, N. Y., Doubleday-Doran, 1926

Thomas, Mrs. Hudson, To Be Continued, Nashvilie, Tenn. Boardman Press, 1938

Withoft, Mabel Swartz, Oak and Laurel, Nashville, Tenn., Boardman Press, 1920

Wharton, Mrs. H. M., Ready Pens for Willing Workers, Birmingham, Ala., W. M. Literature Dept., 1936

Wharton, Mrs. H. M., Fruits of the Years, Atlanta, Ga., Home Mission Board, 1938

White, Blanche, Saved to Serve, Richmond, Va., Rice Press, 1937

Iright, Mrs. Carter, Ruby Anniversary Bulletin, Birmingham, Ala., W. M. U. Ilterature Dept., 1928

\section{PERIODICALS AND PANPHLETS}

Broadus, Eliza, "Some Early History," (unpublished) Kentucky N. M. U. office files

Davis, Mrs . George E., "History of Girl's Auxiliary," World Comrades, Vol. VV:7, Nov. 1937

Hutchis on, Margaret, "Report of Arkansas Young People's Secretary," Minutes of Arkans as U. M. U., 1933, Page 11

Northington, Nary, "Information for State Missions," Pamphlet, 1936

McWilliams, Mrs. George, "Golden Jubilee Manual," Pamphlet, 1937

Ray, Mrs. C. H., "Annual Message of Arkansas State President," Minutes of Arkansas W. M. U., 1933, page 4

Smith, Louise, "Twenty-five Years of Light Bearing in Florida," Pamphlet, 1935 
Convention Record, 1917

Grace McBride, Pamphlet, 1925

Heathen Helper, June 1888, pp. 5--6

Margaret Fund, Pamphlet

ORIGINAL SOURCES

Home Mission Board Report, 1906

Minutes of Southern Baptist Convention, 1880--1937

Minutes of Woman's Missionary Union Annual Meeting, $1890--1937$

Ninutes of Arkansas Baptist Association, 1936

Minutes of General Association of Kentucky Baptist, $1839--1840--1843--1882$

Our Misston Field, Dec. 1910, Jan. 1911, April 1911, Oct. I911

W. N. U. Year Book, 1927--1938

World Comrades, Sept. 1922, June 1924, Sept. 1925, Jan. 1927, May 1930, Aug. 1932, Sept. 1935, May 1936, June 1936, Nov. 1937

Royal Service, Sept. 1922, June 1923, Sept. 1923, Aug. 1924, May 1926, May 1927, Sept. 1928, Nov. 1928, Jan. 1929, llay 1931, June 1931, April 1932, jept. 1934, liay 1936, May 1937, May 1938

The Window of Y.W.A., sept. 1929, Jan. 1932, Feb. 1932, Mar. 1932, April 1932, June 1934, June 1935, June 1936, June 1937

Baptist Witness, May 1934, har. 1937

Baptist and Reflector, Sept. 1935, May 1938

Baptist New Mexican, Mar. 1936, llay 1937, Hay 1938

Western Recorder, July 1928, Feb. 1934, May 1934, Aug. 1934, Nov. 1934 